\title{
Effect of stage of lactation and dietary starch content on endocrine-metabolic status, blood amino acid concentrations, milk yield, and composition in Holstein dairy cows
}

\author{
F. Piccioli-Cappelli, ${ }^{1 *} \oplus$ C. J. Seal, ${ }^{2}$ D. S. Parker, ${ }^{3} \oplus$ J. J. Loor, ${ }^{4} \oplus$ A. Minuti, ${ }^{1} \oplus$ V. Lopreiato, ${ }^{1} \oplus$ and E. Trevisi ${ }^{1} \oplus$ \\ ${ }^{1}$ Department of Animal Sciences, Food and Nutrition (DiANA), Faculty of Agriculture, Food and Environmental Sciences, \\ Università Cattolica del Sacro Cuore, 29122 Piacenza, Italy \\ ${ }^{2}$ Human Nutrition Research Centre, Public Health Sciences Institute, Newcastle University, Newcastle upon Tyne, NE2 4HH, United Kingdom \\ ${ }^{3}$ Pii Nutrition, 37, Thunder Lane, Norwich, NR7 OPX, United Kingdom \\ ${ }^{4}$ Mammalian NutriPhysioGenomics, Department of Animal Sciences and Division of Nutritional Sciences, University of Illinois, Urbana 61801
}

\begin{abstract}
Milk yield and composition are modified by level and chemical characteristics of dietary energy and protein. Those factors determine nutrient availability from a given diet, and once absorbed, they interact with the endocrine system and together determine availability of metabolites to the mammary gland. Four multiparous dairy cows in early lactation and subsequently in late lactation were fed 2 diets for $28 \mathrm{~d}$ in a changeover design that provided, within the same stage of lactation, similar amounts of rumen fermentable feed with either high (HS) or low starch (LS). All diets had similar dietary crude protein $(15.5 \%$ dry matter $)$ and rumen-undegradable protein ( $\sim 40 \%$ of crude protein) content. Profiles of AA were calculated to be similar to that of casein. On d $28,\left[1-{ }^{13} \mathrm{C}\right]$ Leu was infused into one jugular vein with blood samples taken at $0,2,4,6$, and $8 \mathrm{~h}$, and cows milked at $0,2,4,5,6,7$, and $8 \mathrm{~h}$ from start of infusion. Isotopic enrichments of plasma Leu, keto-isocaproic acid, and milk casein were determined for calculation of Leu kinetics. Data were subjected to ANOVA using the MIXED procedure of SAS (SAS Institute Inc.), with time as repeated factor and cow as the random effect. Dry matter intake within each stage of lactation was similar between groups. Feeding LS resulted in lower blood glucose and greater ratio of bovine somatotropin to insulin. This response was associated with greater blood concentrations of nonesterified fatty acids and $\beta$-hydroxybutyrate, which might have contributed to greater milk fat content in LS-fed cows. Except for His, average concentrations of all AA in blood were higher in late than early lactation. Diet
\end{abstract}

Received March 29, 2021.

Accepted October 17, 2021.

*Corresponding author: fiorenzo.piccioli@unicatt.it did not alter average plasma concentrations of AA. However, for most of the essential AA (particularly branched-chain), the HS diet led to a marked decrease in concentrations after the forage meal, resulting in significant differences between dietary groups in early lactation. In early-lactating cows fed HS, a greater reduction in plasma concentrations at $8 \mathrm{~h}$ relative to pre-feeding values (time zero) was observed for Met, Lys, and His, resulting in decreases of $27.9 \%, 33.6 \%$, and $38.5 \%$, respectively. A higher bovine somatotropin/insulin ratio in early lactation and in cows fed LS could possibly have led to greater breakdown and, consequently, higher AA flux from peripheral tissues. In LS-fed cows, higher mobilization of body fat and protein was confirmed by the greater body weight loss in both stages of lactation. Higher irreversible loss of $\left[1-{ }^{13} \mathrm{C}\right]$ Leu in early lactation suggested lower protein retention in peripheral tissues during early compared with late lactation. Milk yield, protein output, and composition were similar between groups at both stages of lactation, whereas milk coagulation was faster (lower curd firming rate) and with higher curd firmness in response to feeding HS in late lactation. Overall, data indicated that rate of carbohydrate fermentability in the rumen can modify the availability of metabolites to the mammary gland and consequently modify milk protein coagulation.

Key words: dairy cow, starch level, metabolism, milk composition

\section{INTRODUCTION}

A large number of studies and reviews on the effects of genetics, nutrition, and environment on the output of milk solids have been published, recognizing the importance of milk solids for industrial use. Protein, in particular the ratio of true protein:casein, and milk fat content are the most important factors influenc- 
ing cheese yield and its quality (Barbano and Sherbon, 1984; Bertoni et al., 2001). Factors that regulate quantity and quality of fat and protein in milk are complex, involving several intrinsic and extrinsic factors. Among the latter, nutrition plays a crucial role as it can markedly modify the quantity and quality of the milk solids output (DePeters and Cant, 1992; Palmquist and Jenkins, 2017).

The positive relationship among the availability of rumen fermentable carbohydrate, bacterial protein yield (Oba and Allen, 2003), and milk true protein output (Broderick, 2003) is well known. The mechanism responsible for this relationship encompasses a lower ruminal acetate:propionate ratio, which results in greater yield of glucose and lower use of glucogenic AA by the liver (Seal et al., 1992; Seal and Reynolds, 1993) and the gut (Piccioli-Cappelli et al., 1997). The result is an increase in insulin release, which in turn stimulates protein synthesis by the mammary gland (Mackle et al., 1999) leading to greater requirements for AA and glucose. Molento et al. (2002) observed significant interactions between insulin and recombinant bovine somatotropin (rbST) administration for milk, protein, and casein yield. Consequently, along with the amount and source of dietary protein (Santos et al., 1998) and AA profile reaching the small intestine (Bach et al., 2000), it can be speculated that the effect of diets with the potential to modify the ruminal acetate:propionate ratio on milk protein content differs across stages of lactation. Mechanistically, this is due to changes in circulating bST:insulin ratio and differences in the responsiveness of insulin to glucose availability during lactation (Bauman, 2000).

Although many studies have evaluated the effects of dietary energy and protein on milk protein production, few have also investigated renneting properties of milk (e.g., rennet coagulation time, curd firmness), which have a central role in cheese yield. Calamari et al. (2010) observed that decreasing dietary starch from $20.7 \%$ to $17.9 \%$ of DM in the diet of dairy cows led to improved renneting properties of the milk. In addition, in a previous study from our group, production of milk with higher curd firmness (a30), in cows treated with recombinant bST was related to an increased content of the $\alpha$-casein fraction (Piccioli-Cappelli et al., 1996).

Considering the available literature, the objective of this work was to investigate in early- and late-lactation dairy cows the effects of diets with similar CP, RUP, and energy content, but different rates of carbohydrate (starch or fermentable fiber) fermentability on (1) endocrine-metabolic conditions; (2) AA metabolism; and (3) composition and renneting properties of milk at each stage of lactation.

\section{MATERIALS AND METHODS}

\section{Animals and Experimental Diets}

This study complied with Italian laws and ethics on animal experimentation (DL n. 116, 27/01/1992). Cows used in this study were the same as those used in a previous study (Piccioli-Cappelli et al., 2014). Briefly, 4 multiparous pregnant Italian-Friesian dairy cows (mean $\pm \mathrm{SD} ; 7.4 \pm 1.7$ yr old, $580 \pm 85 \mathrm{~kg}$ of BW at the beginning of the trial) with average genetic merit $(8,060 \pm 460 \mathrm{~kg}$ of milk in the previous lactation) were used. Cows were housed in an artificially lit (with $14 \mathrm{~h}$ light and $10 \mathrm{~h}$ dark) and temperature-controlled $\left(20^{\circ} \mathrm{C}\right.$, 60-70\% relative humidity) tiestalls at the Università Cattolica del Sacro Cuore (Piacenza, Italy). The study was replicated at 2 stages of lactation: starting at 30 DIM for the early-lactation stage and starting at 177 DIM for the late-lactation stage. Within lactation stage, cows were randomly allocated to 2 groups of 2 cows each, consuming 2 different diets over 2 periods of $28 \mathrm{~d}$ in a crossover experimental design. Diets were (1) a high-starch (HS) and (2) a low-starch content diet (LS), both of which were based on corn silage, hay (alfalfa and perennial grass), and concentrate (Table $1)$. The aim of varying the starch content was to alter production of ruminal propionic acid.

Diets (Table 1) were designed to have rumen fermentable organic matter (FOM; Tamminga et al., 1994) equal to $12.2 \mathrm{~kg} / \mathrm{d}$ during early lactation and $10.4 \mathrm{~kg} / \mathrm{d}$ during late lactation, but in both periods were modified to produce either HS or LS. The resulting 4 diets were similar in CP, rumen soluble protein, and RUP. The RUP was calculated to guarantee the same level of available digestible protein at the intestinal level (calculated according to Tamminga et al., 1994) in HS and LS at each stage of lactation. Across all diets, ingredients were adjusted to provide a predicted AA profile of the intestinal digestible protein (rumen microbial protein plus RUP) similar to that of milk protein.

The following ingredients were used to prepare the diets: corn gluten feed, linseed meal, fish meal, feather meal, nonruminant blood meal (the study was performed before the European Community restriction on the use of animal sources in ruminant nutrition), rumen-protected methionine (Overmet 40\%, Ascor Chimici s.r.l.; methionine content $40 \%$ on an as-fed basis, of which $50 \%$ was tested to be rumen bypass by nylon-bag technique, unpublished data) and rumenprotected lysine (Relys, Vetagro SpA; lysine content $50 \%$ on an as-fed basis, of which $35 \%$ was tested to be rumen bypass by nylon-bag technique, unpublished data). 
In the planning phase of the study, total microbial protein yield was estimated according to Tamminga et al. (1994), and the AA composition derived from the literature. In particular, the AA composition of rumen microbial protein was an average of data reported by
Buttery (1977), Clark et al. (1992), Mantysaari et al. (1989), and Storm and Ørskov (1983) (Supplemental File S1; https://doi.org/10.6084/m9.figshare.14706606 .v2; Piccioli-Cappelli, 2021); for AA composition of RUP, the feed data from Ganev et al. (1979) and Mantysaari

Table 1. Composition on a DM basis and characteristics of the experimental diets with high (HS) or low (LS) starch content and fed in early and late lactation ${ }^{1}$

\begin{tabular}{|c|c|c|c|c|}
\hline \multirow[b]{2}{*}{ Item } & \multicolumn{2}{|c|}{ Early lactation } & \multicolumn{2}{|c|}{ Late lactation } \\
\hline & HS & LS & HS & LS \\
\hline Corn silage, \% & 26.2 & 19.1 & 33.1 & 21.3 \\
\hline Alfalfa hay, \% & 11.5 & 11.3 & 15.8 & 15.5 \\
\hline Grass hay, \% & 9.4 & 18.6 & 9.9 & 23.0 \\
\hline Concentrate, \% & 52.9 & 51.0 & 41.2 & 40.2 \\
\hline \multicolumn{5}{|c|}{ Concentrate composition, $\%$ of DM } \\
\hline Barley flour & 23.82 & 9.60 & 24.68 & 4.30 \\
\hline Beet pulp & 13.87 & 23.26 & 3.10 & 28.27 \\
\hline Soybean meal & 12.36 & 17.34 & 13.80 & 20.40 \\
\hline Corn flour & 11.52 & 10.34 & 12.05 & 7.00 \\
\hline Steam-flaked corn & 11.35 & 9.90 & 12.05 & 7.00 \\
\hline Corn gluten feed & 6.23 & 12.00 & 7.13 & 9.50 \\
\hline Linseed meal & 5.02 & 2.00 & 3.50 & 1.60 \\
\hline Molasses & 3.02 & 1.50 & 6.01 & 1.49 \\
\hline Animal fat & 2.71 & 3.50 & 1.80 & 1.30 \\
\hline Fish meal & 2.46 & 3.50 & 1.80 & 1.30 \\
\hline Feather meal & 2.13 & 1.20 & 2.00 & 0.80 \\
\hline Urea & 0.50 & 0.50 & 0.39 & 0.29 \\
\hline Blood meal $^{2}$ & 0.30 & 0.70 & 0.39 & 0.70 \\
\hline Methionine $^{3}$ & 0.20 & 0.20 & 0.23 & 0.24 \\
\hline Lysine $^{4}$ & 0.10 & 0.05 & 0.05 & 0.05 \\
\hline Wheat bran & - & - & 6.61 & 11.35 \\
\hline Dicalcium phosphate & 1.81 & 1.81 & 1.81 & 1.81 \\
\hline Limestone & 1.10 & 1.10 & 1.10 & 1.10 \\
\hline Magnesium oxide & 0.70 & 0.70 & 0.70 & 0.70 \\
\hline Sodium bicarbonate & 0.50 & 0.50 & 0.50 & 0.50 \\
\hline Salt & 0.30 & 0.30 & 0.30 & 0.30 \\
\hline \multicolumn{5}{|l|}{ Chemical composition } \\
\hline $\mathrm{NE}_{\mathrm{L}}, \mathrm{Mcal} / \mathrm{kg}$ of $\mathrm{DM}$ & 1.58 & 1.56 & 1.53 & 1.49 \\
\hline $\mathrm{CP}, \%$ of $\mathrm{DM}$ & 15.3 & 15.3 & 15.2 & 15.4 \\
\hline Starch, \% of DM & 21.33 & 15.40 & 20.43 & 12.01 \\
\hline Ether extract, \% of DM & 4.26 & 4.37 & 3.57 & 3.35 \\
\hline $\mathrm{NDF}, \%$ of DM & 38.10 & 41.33 & 39.32 & 43.81 \\
\hline $\mathrm{ADF}, \%$ of $\mathrm{DM}$ & 18.95 & 21.53 & 20.27 & 24.42 \\
\hline $\mathrm{ADL}, \%$ of $\mathrm{DM}$ & 3.39 & 3.88 & 3.79 & 4.57 \\
\hline $\mathrm{FOM}^{5} \mathrm{~kg} / \mathrm{d}$ & 12.3 & 12.1 & 10.5 & 10.3 \\
\hline $\mathrm{RUS}^{6}{ }^{6} \mathrm{~kg} / \mathrm{d}$ & 1.15 & 0.96 & 0.93 & 0.55 \\
\hline Microbial protein, ${ }^{7} \%$ of DM & 12.8 & 13.0 & 12.6 & 12.8 \\
\hline $\mathrm{RUP}^{7} \%$ of $\mathrm{CP}$ & 41.3 & 40.8 & 39.5 & 38.8 \\
\hline Soluble protein, ${ }^{7} \%$ of CP & 29.85 & 30.43 & 30.94 & 30.42 \\
\hline $\mathrm{PDI}{ }^{8} \mathrm{~g}$ & 1,836 & 1,736 & 1,585 & 1,446 \\
\hline
\end{tabular}

${ }^{1}$ Dairy cows received $200 \mathrm{~g} / \mathrm{d}$ of barley flour, split into 2 meals and fed with the forages, containing a vitamin and trace mineral mixture providing $150,000 \mathrm{IU}$ of vitamin A, 10,000 IU of vitamin D, $200 \mathrm{mg}$ of vitamin E, $100 \mathrm{mg}$ of vitamin $\mathrm{K}, 100 \mathrm{mg}$ of vitamin $\mathrm{H} 1,50 \mathrm{mg}$ of vitamin $\mathrm{B}_{1}, 0.5 \mathrm{mg}$ of vitamin $\mathrm{B}_{12}, 500 \mathrm{mg}$ of niacin, $4,000 \mathrm{mg}$ of choline, $350 \mathrm{mg}$ of $\mathrm{Mn}, 800 \mathrm{mg}$ of $\mathrm{Zn}, 40 \mathrm{mg}$ of $\mathrm{Cu}, 20 \mathrm{mg}$ of I, $1 \mathrm{mg}$ of Co, $1 \mathrm{mg}$ of Se, $2 \mathrm{~g}$ of DL-methionine.

${ }^{2}$ Not of ruminant origin.

${ }^{3}$ Contained $40 \%$ of Met on an as-fed basis, of which $50 \%$ was undegradable in the rumen.

${ }^{4}$ Contained $50 \%$ of Lys on an as-fed basis, of which $35 \%$ was undegradable in the rumen.

${ }^{5} \mathrm{FOM}=$ fermentable organic matter. Revaluated using INRA (2018) after DMI measurement and feed analyses

${ }^{6}$ Rumen-undegradable starch revaluated using NRC (2001) after feed analyses.

${ }^{7}$ Revaluated using NRC (2001) after feed analyses.

${ }^{8}$ Total AA digestible in the gut calculated according to INRA (2018) after DMI measurement and feed analyses. 
et al. (1989) were used; for the rate of AA absorption in the gut and rate of availability to mammary gland for uptake and inclusion in milk protein, calculations proposed by Riis et al. (1989) were used; for AA composition of milk protein, the means of data reported by Alais (1984), Evans and Patterson (1985), Mantysaari et al. (1989), McCance and Widdowson (1978), and Rohr and Lebzien (1991) were used (Supplemental File S2; https://doi.org/10.6084/m9.figshare.14706606.v2; Piccioli-Cappelli, 2021). Before drafting of the paper, these calculations were revised using the system proposed by INRA (2018), and results obtained for FOM and protein digestible in the gut (PDI) are reported in Table 1. Balance of AA is reported in Supplemental File S3 (https://doi.org/10.6084/m9.figshare.14706606 .v2; Piccioli-Cappelli, 2021).

Forages were fed twice daily at 12 -h intervals (0730 and $1930 \mathrm{~h}$, Figure 1). For every forage meal, corn silage, chopped (at 1-2 cm length) alfalfa, and grass hay were weighed individually according to proportions reported in Table 1 . They were combined before being placed in the feeder, whereas the concentrates (delivered in pelleted form) were fed in 8 equal meals at 3-h intervals during the day using an automatic feeder. Two of the 8 meals were programmed to deliver the concentrate $30 \mathrm{~min}$ before the forage meal. At each DMI variation, the quantity of a single feed (all forages and concentrates) was adjusted, maintaining the fixed proportion of each ingredient in each diet fed to cows at each stage of lactation. Diets were offered ad libitum and until the leftovers (checked every morning) of each ingredient were close to $5 \%$ of that offered. Leftovers were dried, and their amount of DM subtracted from the amount of DM offered to calculate DMI.

\section{$\left[1-{ }^{13} \mathrm{C}\right]$ Leucine Infusions}

On d 28 of each period, cows received an 8-h intrajugular infusion of $\left[1-{ }^{13} \mathrm{C}\right]$ leucine $\left(\left[\mathbf{1 -}{ }^{\mathbf{1 3}} \mathbf{C}\right] \mathrm{Leu}, 99 \%\right.$ atom percent; Mass Trace Inc.) prepared in physiologi-

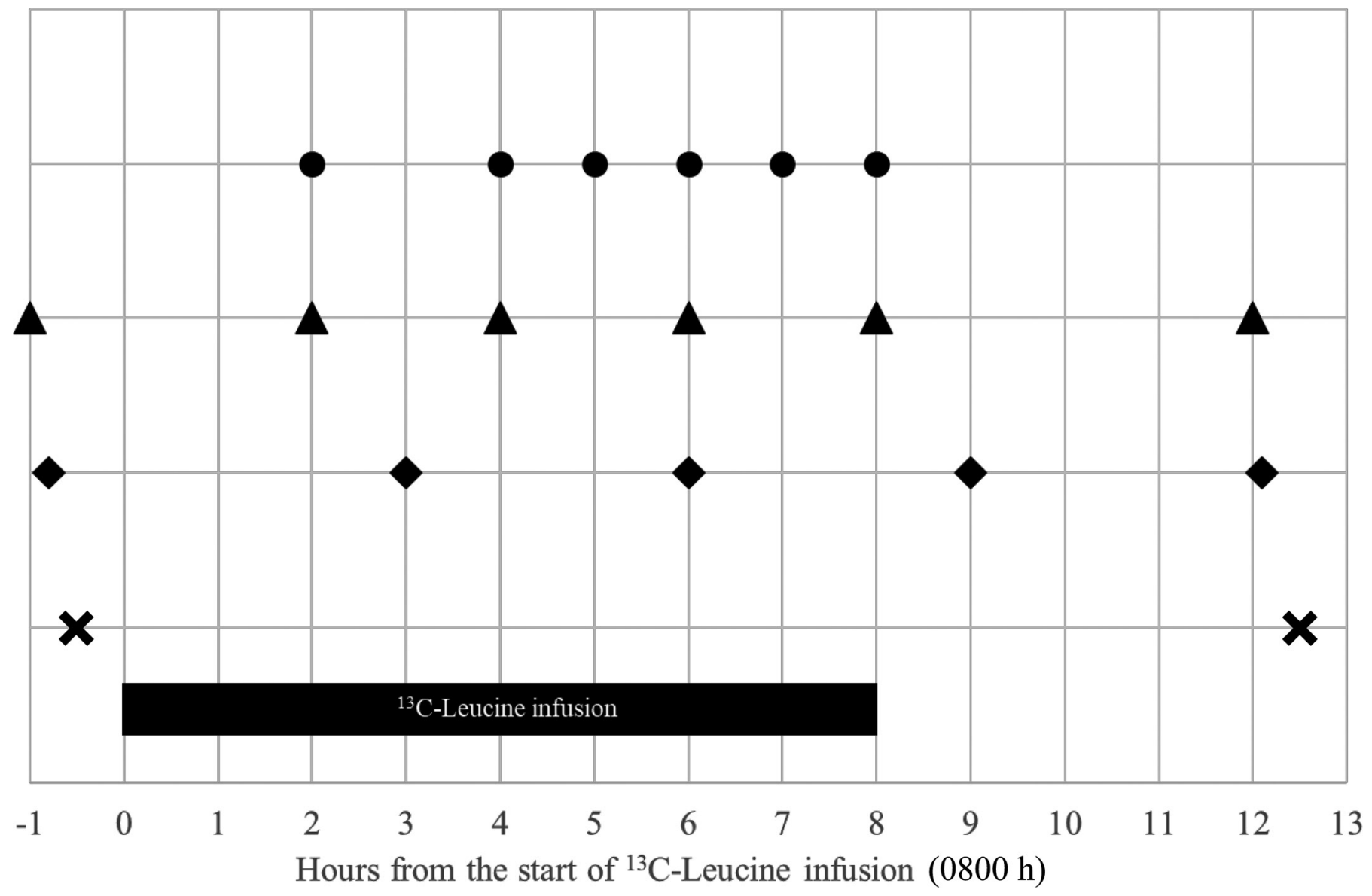

Figure 1. Schematic representation of the treatments and checks carried out on d 28 of each period. $\times$ forages meal; $\bullet$ concentrate meal; $\Delta$ blood sampling; $\bullet$ milk sampling. 
cal saline and infused at a rate of $50 \mu \mathrm{g}\left[1-{ }^{13} \mathrm{C}\right] \mathrm{Leu} / \mathrm{kg}$ metabolic BW per minute (approximately $2 \mathrm{~mL} / \mathrm{min}$ ). Infusions started at $0800 \mathrm{~h}(0.5 \mathrm{~h}$ after the morning forage feed) and finished with the afternoon milking fixed for this day at $1600 \mathrm{~h}$.

\section{Feed Intake and Diet Composition}

Throughout the experimental periods, samples of forages were collected twice per week and pooled on a monthly basis, whereas corn silage and concentrates were sampled fortnightly and pooled for each experimental period. Analysis and nutritive value of feeds were determined in the representative samples using standard procedures (AOAC International, 2012).

\section{Health Status, BW, and BCS Evaluation}

Health of the cows was monitored throughout the whole experimental period on the basis of feed intake, milk yield, and measuring rectal temperature twice a week. Cows were weighed at the beginning of each experimental period and on d 14 and 28 of each period. On the same days, BCS was evaluated using the 5-point scale proposed by Edmonson et al. (1989) by the same evaluator throughout the study.

\section{Blood Sampling and Analyses}

A catheter (Endocath 2.0, Plastimed Cedex) for $\left[1-{ }^{13} \mathrm{C}\right]$ Leu infusion was inserted in a jugular vein the day before the infusion. After insertion the catheter was filled with a heparin solution $(50 \mathrm{UI} / \mathrm{mL}$ in sterile saline). After disinfecting the point of insertion, the external part of the catheter (Luer lock junction and stopper) was covered with a self-adhesive elastic bandage. The following day the patency of the catheter was checked before starting the infusion and at the end of the infusion the catheter was removed and the point of insertion disinfected again with antibiotic ointment. On d 28 of each period, blood samples were taken from the jugular vein a few minutes before the concentrate meal (basal samples, time 0, also for $\left[1-{ }^{13} \mathrm{C}\right]$ Leu enrichment) and at $2,4,6,8$, and $12 \mathrm{~h}$ from the start of $\left[1-{ }^{13} \mathrm{C}\right] \mathrm{Leu}$ infusion (Figure 1). Blood samples were collected from the opposite jugular vein to that of the infusion, and in the case of concomitance of concentrate meal and blood sampling times, blood sampling was performed a few minutes before the concentrate meal was fed. Blood samples were withdrawn into 10-mL heparinized vacuum tubes (Vacutainer, Becton Dickinson) and immediately placed in iced water until centrifugation.
Blood samples were centrifuged within $1 \mathrm{~h}$ from collection at $3,500 \times g$ for $16 \mathrm{~min}$ at $6^{\circ} \mathrm{C}$. The plasma obtained was divided into 5 fractions; 3 were stored at $-20^{\circ} \mathrm{C}$ for analysis of metabolites and hormones and 2 at $-80^{\circ} \mathrm{C}$ for analysis of free AA, keto-isocaproic acid (KIC), Leu, and $\mathrm{KIC}{ }^{13} \mathrm{C}$ enrichment. On plasma collected at $0,2,4,6,8$, and $12 \mathrm{~h}$, concentrations of glucose, urea, nonesterified fatty acids (NEFA), and $\mathrm{BHB}$ were analyzed at $37^{\circ} \mathrm{C}$ with a clinical centrifugeanalyzer (Monarch 2000, Instrumentation Laboratory) using methods described by Piccioli-Cappelli et al. (2014). On the same samples, plasma concentrations of bST and insulin were determined by double antibody RIA using the methods described by Piccioli-Cappelli et al. (2014).

Concentrations of free AA were determined in plasma collected at 0,4 , and $8 \mathrm{~h}$ from the $\left[1-{ }^{13} \mathrm{C}\right]$ Leu infusions via reversed-phase HPLC after filtration through $10 \mathrm{~K}$ molecular weight filters (Millipore UK Ltd.) and precolumn derivatization with phenylisothiocyanate using a Waters Pico-Tag System (Waters Chromatography Division, Millipore).

\section{Analyses of Plasma $\left[1-{ }^{13} \mathrm{C}\right] \mathrm{Leu},\left[1-{ }^{13} \mathrm{C}\right] \mathrm{KIC}$ Enrichment, and Calculation of Irreversible Loss Rate}

Details are described in Piccioli-Cappelli et al. (1997). Briefly, Leu and KIC enrichments were determined in plasma collected at $0,2,4,6$, and $8 \mathrm{~h}$ after separation of tert-butyl-dimethylsilyl derivatives using an electron-impact selective ion monitoring of mass fragments (Finnigan MAT 1050 GC mass spectrometer) fitted with a $30 \mathrm{~m}$ DB5 capillary column $(0.25 \mathrm{~mm}$ i.d., $0.25 \mu \mathrm{m}$ coating). Whole-body Leu irreversible loss rate (Leu-ILR) was calculated with the formula proposed by Lapierre et al. (1999):

$$
\begin{aligned}
& \text { whole-body Leu-ILR }= \\
& \frac{\text { rate of Leu infusion } \times \text { KIC isotopic enrichment }}{\text { Leu isotopic enrichment in precursor pool }} .
\end{aligned}
$$

Casein ${ }^{13} \mathrm{C}$ enrichment was calculated using Pee-Dee Belemnite (PDB) as the reference and expressed as difference $(\boldsymbol{D P D B})$ with respect to $\mathrm{PDB}$ at time zero $\left({ }^{13} \mathrm{C} /{ }^{12} \mathrm{C}\right.$ before infusion start $)$.

Whole-body protein flux (WBPF) was calculated from Leu-ILR as proposed by Bequette et al. (1996):

$$
\begin{aligned}
& \mathrm{WBPF}=\{[\text { Leu-ILR }(\mathrm{mmol} / \mathrm{h}) \times 131.18] / 61.4\} \\
& \times 24(\mathrm{~h})
\end{aligned}
$$


and its value was used to calculate the proportion secreted with mammary gland protein $(\mathbf{M G P})=\mathrm{MGP} /$ WBPF (Table 6).

\section{Milk Sampling and Analyses}

Cows were milked twice daily at 0630 and $1630 \mathrm{~h}$ throughout lactation. During $\left[1-{ }^{13} \mathrm{C}\right]$ Leu infusion, cows were milked before the beginning of the infusion and after $2,4,5,6,7$, and $8 \mathrm{~h}$ for casein separation by precipitation as described below. Milk yield was individually recorded during each experimental period. Representative samples of the morning milking were collected every Monday and Thursday, kept in a water bath at $28^{\circ} \mathrm{C}$, and used within $2 \mathrm{~h}$ for measurement of fat, protein, and lactose content by mid-infrared analyzer (MilkoScan 133B, Foss Electric), pH with a combined electrode, and titratable acidity measuring the milliliters of $\mathrm{NaOH} 0.25 \mathrm{~N}$ necessary to stabilize the $\mathrm{pH}$ of $50 \mathrm{~mL}$ of milk at $8.65 \mathrm{using}$ an automatic titrator (Crison Micro TT 2050).

Ten milliliters of milk was used to measure the renneting properties adding $0.2 \mathrm{~mL}$ of rennet $(\mathrm{Chr}$. Hansen $\mathrm{A} / \mathrm{S}, 1: 15,000$ in a $1.5 \% \mathrm{vol} / \mathrm{vol}$ solution in distilled water) and measuring the tromboelastogram at $35^{\circ} \mathrm{C}$ for a total time of $30 \mathrm{~min}$ using the Formagraph (Foss Electric). The lag time ( $\mathrm{min}$ ) before the beginning of coagulation was defined as the rennet clotting time, the time ( $\mathrm{min})$ necessary to reach 20 $\mathrm{mm}$ of width of the thrombus was defined as curd firming rate $(\mathbf{k 2 0})$, whereas the width of the thrombus after $30 \mathrm{~min}(\mathrm{~mm})$ was defined as curd firmness (a30). Somatic cell counts were determined using a Fossomatic automated somatic cell counter (Fossomatic 180, Foss Electric).

During the last $10 \mathrm{~d}$ of each experimental period, milk samples from afternoon (on Sunday and Wednesday) and morning (Monday and Thursday) milking were bulked proportionally based on respective milk yield and stored at $-20^{\circ} \mathrm{C}$ in 5 aliquots of $10 \mathrm{~mL}$ each. At the time of analyses, an aliquot was thawed in a water bath at $42^{\circ} \mathrm{C}$. Fat, protein, and lactose were measured as above. Urea was determined in skim milk (obtained after centrifuged at $3,500 \times g$ for $16 \mathrm{~min}$ at $6^{\circ} \mathrm{C}$ and removal of the fat layer) by a spectrometric assay, using the method used for blood urea.

For analyses of calcium and phosphorus, $0.25 \mathrm{~mL}$ of raw milk was pipetted into 10 -mL glass vials and dried overnight in a ventilated oven at $105^{\circ} \mathrm{C}$. Once cold, 1 $\mathrm{mL}$ of concentrated perchloric acid was added to the dried milk and mineralized on a heater block at $180^{\circ} \mathrm{C}$, with addition of $0.3-\mathrm{mL}$ aliquots of hydrogen peroxide (Superpur, Merck) until complete transparency was achieved. After cooling, $1 \mathrm{~mL}$ of mineralized solution of samples was added to $9 \mathrm{~mL}$ of distilled water and minerals determined using an ICP-OES Optima 2100 (PerkinElmer Inc.). Analyses of samples with known calcium and phosphorus contents were run in parallel.

To quantify milk protein fractions and measure ${ }^{13} \mathrm{C}$ enrichment, casein and whey protein were separated using the method proposed by Harding and Marshall (1998). For quantification of the milk protein fraction, the method described by Davoli (1981) was followed. Briefly, $5 \mathrm{~mL}$ of skim milk (obtained as described above) was added to $0.5 \mathrm{~mL}$ of $10 \%$ (vol/vol) acetic acid, and the vials were capped, mixed, and left in a water bath at $40^{\circ} \mathrm{C}$ for $10 \mathrm{~min}$. After cooling to room temperature, $0.5 \mathrm{~mL}$ of a $1 \mathrm{~N}$ solution of sodium acetate was added to the vials, mixed, and centrifuged at 3,000 $\times g$ for $10 \mathrm{~min}$ at $6^{\circ} \mathrm{C}$. Five milliliters of supernatant was kept for whey analyses. After removing the rest of the supernatant, a sample of the casein pellet was kept for determination of ${ }^{13} \mathrm{C}$ enrichment of casein using the method described by Bequette et al. (1996). The rest of the casein pellet was solubilized with $5 \mathrm{~mL}$ of urea $6 M(\mathrm{wt} / \mathrm{vol})$ and $50 \mu \mathrm{L}$ of 2-mercaptoethanol added. Five microliters of this solution was loaded on a strip of cellulose acetate (Sartorius, AG) previously immersed for $10 \mathrm{~min}$ in the running buffer (Tris-glycine $\mathrm{pH}>9$ with addition of urea $6 \mathrm{M}$, wt/vol, and $1.5 \mathrm{~mL}$ of 2-mercaptoethanol per liter of buffer), and afterward placed on the bridge and left to absorb excess buffer. Electrophoresis was carried out in a chamber (model 2001, Pratiga) filled with running buffer at $250 \mathrm{~V}$ for $90 \mathrm{~min}$. After electrophoresis, strips were immersed for 5 min in dye solution (Ponceau Red 2.5\% wt/vol in a solution of $5 \% \mathrm{wt} / \mathrm{vol}$ trichloroacetic acid) and decolored with several passages in a solution of acetic acid $5 \%(\mathrm{vol} / \mathrm{vol})$.

Total whey proteins were analyzed at $37^{\circ} \mathrm{C}$ by clinical centrifuge-analyzer (Monarch 2000, Instrumentation Laboratory) using a kit (IL Test) purchased from Instrumentation Laboratory. For whey protein separation, $5 \mu \mathrm{L}$ of whey was loaded on a strip of cellulose acetate (Sartorius, AG) previously immersed for $10 \mathrm{~min}$ in the running buffer (Tris-glycine $\mathrm{pH}>9$ ) and the excess buffer dried with tissue paper. Electrophoresis was carried out in a chamber filled with running buffer at $250 \mathrm{~V}$ for $150 \mathrm{~min}$. After electrophoresis, strips were immersed for 5 min in dye solution (Ponceau Red 2.5\% $\mathrm{wt} / \mathrm{vol}$ in a solution of $5 \% \mathrm{wt} / \mathrm{vol}$ trichloroacetic acid) and decolored with several passages in a solution of acetic acid 5\% (vol/vol). Both casein and whey protein were quantified using the densitometer Preference (Sebia). Results were expressed for the casein fraction as $\%$ of total casein (calculated by subtracting the total whey protein from the total milk protein), and for whey protein as $\%$ of total milk protein. 


\section{Statistical Analysis}

The experiment was designed to provide a detection power $>0.80$ and a statistical significance at $P<0.05$ using the $\mathrm{G}^{*}$ Power package (Faul et al., 2007). The effect size (f) was calculated using the variance of blood parameters (mainly glucose and insulin) observed in our previous studies using similar protocols. Cows were all in good health throughout the experiment, such that no cow or scheduled tasks were missed. The normal distribution of the data was checked using Proc UNIVARIATE (release 9.1, SAS Institute Inc.) with the NORMAL statement. Data were subjected to ANOVA using the MIXED procedure for repeated measures (h during the day for blood parameters, day after beginning of administration of the diet for milk parameters) of SAS, where cows were the random effect, according to the following model:

$$
\mathrm{Y}_{\mathrm{ijkl}}=\mu+\mathrm{C}_{\mathrm{i}}+\mathrm{D}_{\mathrm{j}}+\mathrm{T}_{\mathrm{k}}+\mathrm{S}_{\mathrm{l}}+\mathrm{DS}_{\mathrm{jl}}+\mathrm{e}_{\mathrm{ijkl}},
$$

where $\mathrm{Y}_{\mathrm{ijkl}}=$ dependent variable, $\mu=$ overall mean, $\mathrm{C}_{\mathrm{i}}=$ effect of the ith cow $(4$ cows $), \mathrm{D}_{\mathrm{j}}=$ effect of the jth diet (HS, LS), $T_{k}=$ effect of the kth hour of blood sampling $(0,2,4,6,8$, and $12 \mathrm{~h}$ for metabolites and 0,4 , and $8 \mathrm{~h}$ for AA) or kth day of milk sampling (14, $17,21,24$, and $28 \mathrm{~d}$ from the beginning of the trial for morning milk, 21, 24, and $28 \mathrm{~d}$ from the beginning of the trial for bulked milk), $S_{1}=$ effect of the lth stage of lactation (early and late lactation), $\mathrm{DS}_{\mathrm{jl}}=$ interaction between the jth diet and the lth stage of lactation, and $\mathrm{e}_{\mathrm{ijkl}}=$ residual error. Effect of sequence of treatment was not included as once evaluated it was always not significant $(P>0.15)$.

Each variable was subjected to 3 covariance structures: first order autoregressive, compound symmetry, and spatial power. The covariance structure with the lowest value of the Akaike's information criterion was chosen for each variable (Littell et al., 2006). For each treatment, least squares means were computed, and pairwise comparisons (PDIFF option; SAS Institute Inc.) were conducted when the $F$-test of one of the main factors (diet, stage of lactation, and diet $\times$ stage of lactation) was significant at $P<0.05$. Statistical significance was designated as $P<0.05$ and tendencies at $P<0.10$.

\section{RESULTS}

\section{Composition of Diets and Nutrient Intake}

Ingredients and nutrient content of experimental diets are presented in Table 1, and Table 2 contains the main characteristics of the feeds used to formulate the diets. Diet formulation resulted in similar FOM, CP, microbial protein, RUP, and soluble protein contents between diets within each stage of lactation. However, calculated rumen-undegradable starch and digestible AA were greater at both stages of lactation when diets with HS were fed.

\section{$D M I, B W$, and $B C S$}

Daily DMI (Table 3) did not differ between the diets within stage of lactation, but DMI was higher in early compared with late lactation $(P<0.01)$. Average BW (Table 3) during the last $14 \mathrm{~d}$ of each period was not affected by diet, although it was numerically lower in both groups during late lactation. Daily body weight (DBW) changes during the last $14 \mathrm{~d}$ of each stage of lactation were affected by diet $(P=0.04)$. During the last $14 \mathrm{~d}$ of the early-lactation period, cows fed the HS diet gained a small amount of weight, whereas cows fed the LS diet lost weight $(P<0.05$ for the difference

Table 2. Gross composition (\% of DM unless otherwise noted) and nutritional traits of feeds used to compose the diets with high (HS) and low (LS) starch contents and fed in early and late lactation

\begin{tabular}{|c|c|c|c|c|c|c|c|c|c|c|}
\hline \multirow[b]{3}{*}{ Composition } & \multicolumn{5}{|c|}{ Early } & \multicolumn{5}{|c|}{ Late } \\
\hline & \multirow{2}{*}{$\begin{array}{c}\text { Corn } \\
\text { silage }\end{array}$} & \multicolumn{2}{|c|}{ Hay } & \multicolumn{2}{|c|}{ Concentrate } & \multirow{2}{*}{$\begin{array}{c}\text { Corn } \\
\text { silage }\end{array}$} & \multicolumn{2}{|c|}{ Hay } & \multicolumn{2}{|c|}{ Concentrate } \\
\hline & & Alfalfa & Grass & HS & LS & & Alfalfa & Grass & HS & LS \\
\hline DM, \% & 30.07 & 90.33 & 90.09 & 90.83 & 90.84 & 34.20 & 89.70 & 89.77 & 89.98 & 91.07 \\
\hline $\mathrm{CP}$ & 6.91 & 14.84 & 8.23 & 21.03 & 21.13 & 6.89 & 18.08 & 9.55 & 21.11 & 22.10 \\
\hline Ether extract & 2.58 & 1.46 & 1.27 & 6.38 & 6.80 & 2.49 & 1.20 & 1.41 & 5.95 & 5.81 \\
\hline $\mathrm{NDF}$ & 52.37 & 50.62 & 62.15 & 25.35 & 28.08 & 50.01 & 47.30 & 59.63 & 22.17 & 27.91 \\
\hline $\mathrm{ADF}$ & 26.78 & 31.24 & 34.50 & 9.64 & 12.74 & 26.78 & 31.24 & 34.50 & 7.19 & 14.82 \\
\hline $\mathrm{ADL}$ & 3.35 & 8.40 & 7.60 & 1.57 & 1.67 & 3.35 & 8.40 & 7.60 & 1.39 & 2.00 \\
\hline Starch & 24.40 & 0.50 & 1.00 & 27.97 & 20.71 & 23.11 & 1.83 & 1.73 & 30.21 & 16.00 \\
\hline $\mathrm{NE}_{\mathrm{L}}, \mathrm{Mcal} / \mathrm{kg}$ & 1.51 & 1.16 & 1.08 & 2.12 & 2.06 & 1.50 & 1.20 & 1.11 & 2.12 & 2.08 \\
\hline
\end{tabular}


Table 3. Mean DMI, BW, daily BW variation (DBW), and BCS in dairy cows in early and late lactation and fed diets with high (HS) and low (LS) starch content

\begin{tabular}{|c|c|c|c|c|c|c|c|c|}
\hline \multirow[b]{2}{*}{ Item } & \multicolumn{2}{|c|}{ Early lactation } & \multicolumn{2}{|c|}{ Late lactation } & \multirow[b]{2}{*}{ SEM } & \multicolumn{3}{|c|}{$P$-value ${ }^{1}$} \\
\hline & HS & LS & HS & LS & & Diet & Stage & Diet $\times$ stage \\
\hline $\mathrm{BW}, \mathrm{kg}$ & 602 & 600 & 588 & 576 & 9 & 0.52 & 0.14 & 0.61 \\
\hline DBW, $\mathrm{kg} / \mathrm{d}$ & $0.39^{\mathrm{a}}$ & $-0.26^{\mathrm{b}}$ & 0.33 & 0.05 & 0.13 & 0.04 & 0.41 & 0.25 \\
\hline $\mathrm{BCS}^{2}$ & 2.32 & 2.27 & 2.46 & 2.36 & 0.05 & 0.25 & 0.13 & 0.62 \\
\hline
\end{tabular}

${ }^{\mathrm{a}, \mathrm{b}}$ Least squares means in the same row and within a stage of lactation without a common superscript differ at $P<0.05$.

${ }^{1}$ Stage $=$ stage of lactation.

${ }^{2}$ Edmonson et al. (1989).

between diets). During late lactation, cows fed the HS diet also gained weight, whereas the weight of cows fed the LS diet did not change, but this difference was not significant. Overall, there was no difference in DBW variation between stage of lactation. Body condition score and its variation were not affected by diet or stage of lactation.

\section{Plasma Metabolites and Hormones}

Overall, diet affected the concentration of postfeeding plasma metabolites with lower concentrations of NEFA and BHB and greater concentrations of glucose in HSfed compared with LS-fed cows (Table 4). This was most marked during early lactation when cows fed the HS diet had lower plasma concentrations of NEFA and $\mathrm{BHB}$, and greater concentrations of glucose compared with LS-fed cows (diet $\times$ stage; $P<0.05$ ), whereas no significant differences were observed in late lactation $(P>0.10)$.

Mean postfeeding concentrations of bST were higher in early compared with late lactation $(P=0.01$; Table $4)$. In both stages of lactation, postfeeding mean concentrations of bST were numerically lower in HS-fed compared with LS-fed cows. Concentrations of insulin after feeding were lower in early compared with late lactation $(P<0.02$; Table 4$)$. During both stages of lactation, plasma concentrations of insulin were greater in HS-fed compared with LS-fed cows $(P<0.05$ for early lactation; $P<0.1$ for late lactation; Table 4$)$. This difference was greatest at 2,8 , and $12 \mathrm{~h}$ after feeding in early lactation and at 2 and $4 \mathrm{~h}$ after feeding in late lactation (Figure 2). The bST/insulin ratio was higher in early compared with late lactation $(P<0.01$, Table 4), and was greater in cows fed LS than HS diets $(P<0.05$ in early lactation; $P<0.1$ in late lactation, Table 4).

\section{Plasma AA}

Plasma free AA concentrations were affected by stage of lactation, diet, and time after feeding of forages (Table 5). Overall, total plasma concentrations of AA were lower in early compared with late lactation $(P<0.05$; Table 5) and this difference was also observed for EAA $(P<0.05)$, NEAA $(P<0.05)$, and branched-chain AA $(P<0.05$; Table 5$)$. After feeding of the forage meal (times 4 and $8 \mathrm{~h}$ ), plasma concentrations of most AA decreased, and this response was more evident in early compared with late lactation and in HS-fed compared

Table 4. Least squares means of average postfeeding concentration (of sampling at 2, 4, 6, 8, and $12 \mathrm{~h}$ after morning forage meal) of blood metabolites and hormones in dairy cows fed 28-d diets with high (HS) and low (LS) starch plus sugar contents during early and late lactation

\begin{tabular}{|c|c|c|c|c|c|c|c|c|}
\hline \multirow[b]{2}{*}{ Item } & \multicolumn{2}{|c|}{ Early lactation } & \multicolumn{2}{|c|}{ Late lactation } & \multirow[b]{2}{*}{ SEM } & \multicolumn{3}{|c|}{$P$-value ${ }^{1}$} \\
\hline & HS & LS & HS & LS & & Diet & Stage & Diet $\times$ stage \\
\hline Glucose, $\mathrm{mmol} / \mathrm{L}$ & $3.95^{\mathrm{a}}$ & $3.48^{\mathrm{b}}$ & 3.70 & 3.65 & 0.05 & $<0.01$ & 0.33 & 0.01 \\
\hline $\mathrm{NEFA},{ }^{2} \mathrm{mmol} / \mathrm{L}$ & $0.04^{\mathrm{a}}$ & $0.13^{\mathrm{b}}$ & 0.04 & 0.05 & 0.02 & 0.02 & 0.03 & 0.02 \\
\hline $\mathrm{BHB}, \mathrm{mmol} / \mathrm{L}$ & $0.51^{\mathrm{a}}$ & $0.91^{\mathrm{b}}$ & 0.56 & 0.59 & 0.08 & 0.03 & 0.10 & 0.05 \\
\hline Urea, mmol/L & 5.18 & 5.45 & 5.24 & 5.47 & 0.30 & 0.13 & 0.75 & 0.90 \\
\hline $\mathrm{bST}, \mathrm{ng} / \mathrm{mL}$ & 2.53 & 2.90 & 1.55 & 1.90 & 0.19 & 0.16 & 0.01 & 0.97 \\
\hline
\end{tabular}

\footnotetext{
$\overline{\mathrm{a}, \mathrm{b}}$ Least squares means in the same row and within a stage of lactation without a common superscript differ at $P<0.05$.

${ }^{\mathrm{c}, \mathrm{d}}$ Least squares means in the same row and within a stage of lactation without a common superscript differ at $P<0.1$.

${ }^{1}$ Stage $=$ stage of lactation; diet $\times$ stage $=$ interaction between diet and stage of lactation.

${ }^{2} \mathrm{NEFA}=$ nonesterified fatty acids.
} 
with LS-fed cows. In early lactation, concentrations of Ala, Arg, Ile, Lys, Met, Orn, Pro, Ser, Tau, and Tyr decreased after feeding with both diets, whereas concentrations of Asn, Cit, Glu, His, Leu, Val, Thr, and Trp decreased only in the HS-fed cows (Table 5). Differences between diets were observed only in early lactation for EAA, where concentrations were lower at $8 \mathrm{~h}$ after the forage meal in HS-fed cows $(P<0.05)$.
Within the EAA, concentrations of branched-chain AA (Ile, Leu, Val) were always lower in HS-fed cows $(P<$ $0.05)$ with these differences observed at all time points; $P<0.05$ at zero time, $P<0.01$ at 4 and $8 \mathrm{~h}$ after the forage meal. During early lactation, there was a tendency $(P<0.10)$ for concentrations of Arg, Cit, Lys, Met, and Phe to be lower in HS-fed cows particularly at $8 \mathrm{~h}$ after the forage meal.
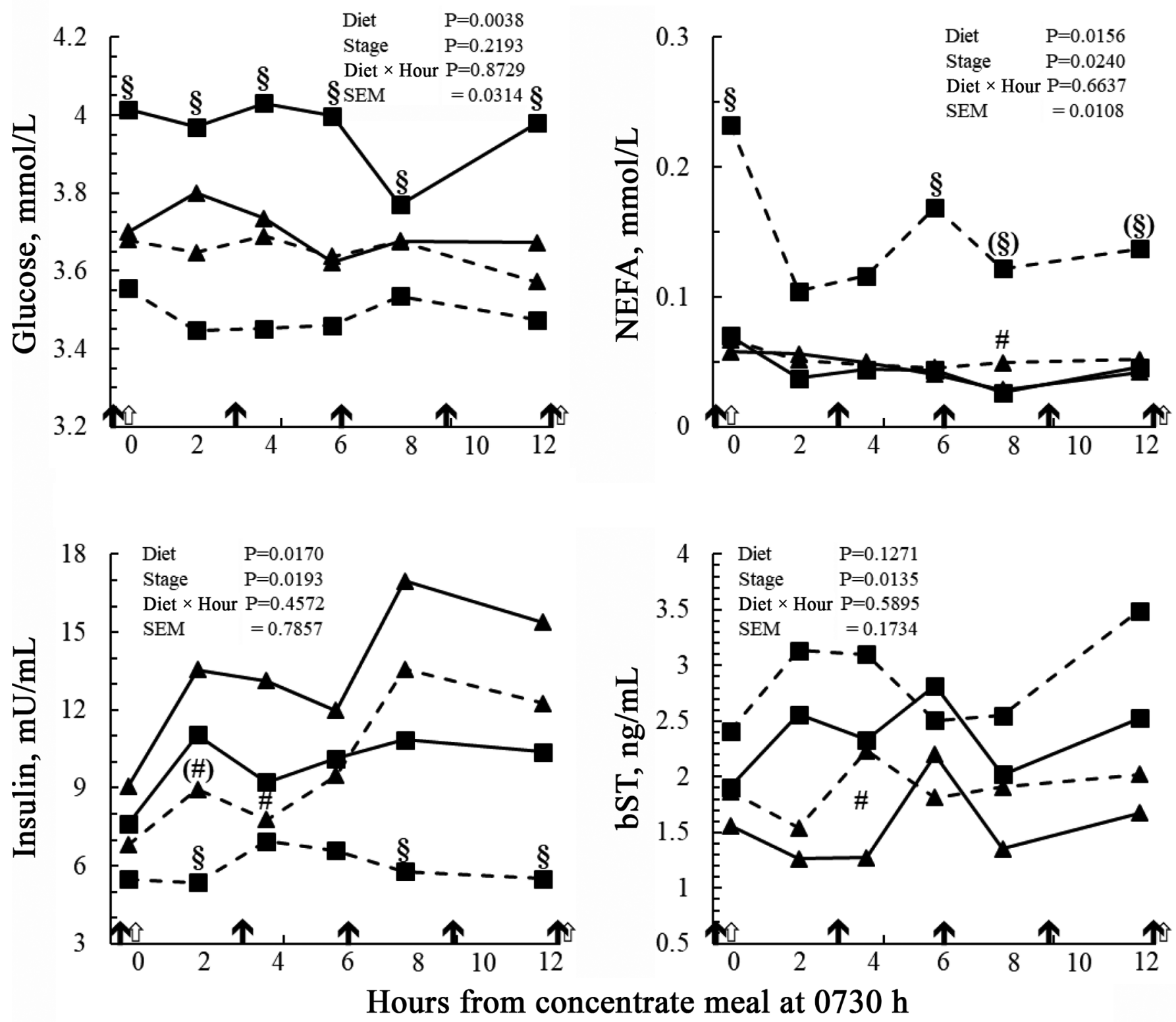

Figure 2. Daily pattern of changes in blood glucose, nonesterified fatty acids (NEFA), insulin, and bST in dairy cows in early ( $\mathbf{\square})$ and late (ム) lactation fed 28-d diets with a high (HS; - ) and low (LS; - - ) starch and sugar content; blood was collected on d 28. A significant difference between HS and LS diets within the same stage of lactation is denoted by $\S$ in early lactation and by \# in late lactation for $P<0.05$, and by $(\S)$ in early lactation and by $(\#)$ in late lactation for $P<0.1$. A white arrow indicates forage meal; a black arrow indicates concentrate meal. 
Table 5. Least squares means of plasma AA concentration ( $\mu$ mol/L) in dairy cows fed 28-d diets with high (HS) and low (LS) starch plus sugar contents during early and late lactation (data collected on last day of period) ${ }^{1}$

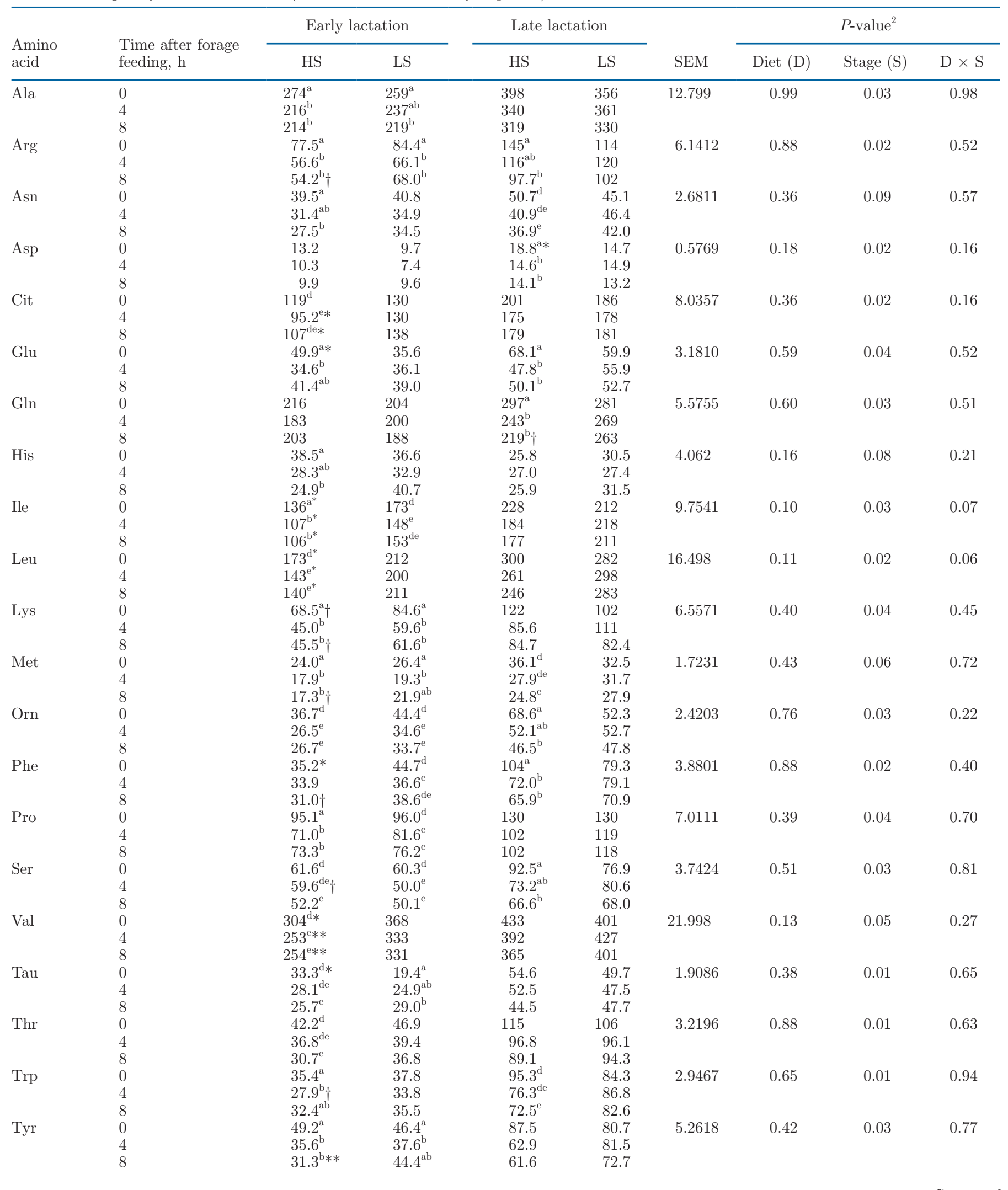


Table 5 (Continued). Least squares means of plasma AA concentration ( $\mu$ mol/L) in dairy cows fed 28-d diets with high (HS) and low (LS) starch plus sugar contents during early and late lactation (data collected on last day of period) ${ }^{1}$

\begin{tabular}{|c|c|c|c|c|c|c|c|c|c|}
\hline $\begin{array}{l}\text { Amino } \\
\text { acid }\end{array}$ & $\begin{array}{l}\text { Time after forage } \\
\text { feeding, } h\end{array}$ & \multicolumn{2}{|c|}{ Early lactation } & \multicolumn{2}{|c|}{ Late lactation } & SEM & \multicolumn{3}{|c|}{$P$-value ${ }^{2}$} \\
\hline \multirow[t]{3}{*}{ EAA } & 0 & $858^{\mathrm{a} *}$ & $1,031^{\mathrm{d}}$ & 1,460 & 1,331 & \multirow[t]{3}{*}{62.307} & \multirow[t]{3}{*}{0.20} & \multirow[t]{3}{*}{0.02} & \multirow[t]{3}{*}{0.34} \\
\hline & 4 & $692^{\mathrm{b} *}$ & $902^{\mathrm{e}}$ & 1,222 & 1,375 & & & & \\
\hline & 8 & $682^{\mathrm{b} * *}$ & $930^{\mathrm{de}}$ & 1,151 & 1,285 & & & & \\
\hline \multirow[t]{2}{*}{ BCAA } & 0 & $614^{\mathrm{a} *}$ & 754 & 961 & 896 & \multirow[t]{2}{*}{47.301} & \multirow[t]{2}{*}{0.11} & \multirow[t]{2}{*}{0.04} & \multirow[t]{2}{*}{0.30} \\
\hline & 4 & $502^{\mathrm{b} * *}$ & 680 & 837 & 943 & & & & \\
\hline \multirow{2}{*}{ NEAA } & 4 & $1,018^{\mathrm{b}}$ & 1,132 & $1,578^{\mathrm{de}}$ & 1,696 & \multirow{2}{*}{42.083} & \multirow{2}{*}{0.82} & \multirow{2}{*}{0.02} & \multirow{2}{*}{0.77} \\
\hline & 8 & $1,062^{\mathrm{b}}$ & 1,128 & $1,487^{\mathrm{e}}$ & 1,583 & & & & \\
\hline \multirow[t]{3}{*}{ TOTAA } & 0 & $2,132^{\mathrm{a}}$ & 2,269 & $3,391^{\mathrm{d}}$ & 3,046 & \multirow[t]{3}{*}{100.73} & \multirow[t]{3}{*}{0.44} & \multirow[t]{3}{*}{0.02} & \multirow[t]{3}{*}{0.52} \\
\hline & 4 & $1,710^{\mathrm{b}}$ & 2,034 & $2,800^{\mathrm{de}}$ & 3,071 & & & & \\
\hline & 8 & $1,744^{\mathrm{b}}$ & 2,057 & $2,639^{\mathrm{e}}$ & 2,868 & & & & \\
\hline
\end{tabular}

\footnotetext{
${ }^{\mathrm{a}, \mathrm{b}}$ Least squares means of single AA for time 0,4 , and 8 within the column without a common superscript differ at $P<0.05$.

${ }^{c-e}$ Least squares means of single AA for time 0,4 , and 8 within the column without a common superscript differ at $P<0.1$.

${ }^{1} \mathrm{EAA}=$ sum of Arg, His, Lys, Met, Phe, Thr, and Trp; BCAA = sum of Leu, Ile, and Val; NEAA = sum of Ala, Asn, Asp, Cit, Glu, Gln, Orn, Pro, Ser, Tau, and Tyr; TOTAA = sum of all AA in the table.

${ }^{2}$ Stage $=$ stage of lactation; $\mathrm{D} \times \mathrm{S}=$ interaction between diet and stage of lactation.

Least squares means of single AA in the same row and within a stage of lactation without a common superscript differ at ${ }^{* *} P<0.01$, or $* P<$ 0.05 , or $\dagger P<0.1$.
}

In late lactation, differences between diets were observed only for Asp (lower in LS-fed cows at time zero, $P<0.05$ ) and Gln (lower in HS-fed cows at the 8-h time point, $P<0.10$ ), whereas decreases in concentrations after the forage meal were observed only in HS-fed cows for Arg, Asp, Glu, Gln, Orn, Phe, and Ser $(P<0.05)$, and for Asn, Met, and Trp $(P<0.10)$.

\section{Leu Metabolism}

Enrichment (atom percent excess, APE) of ketoisocaproic acid (KIC-APE) was not affected by diet or lactation stage (Table 6). The Leu-ILR, calculated from plasma KIC enrichments, which reflects intracellular Leu enrichment, was higher in early compared with late lactation $(P=0.09)$, whereas no difference was observed between HS and LS diet groups (Table 6).
The change in enrichment of the whole casein fraction due to incorporation of $\left[1-{ }^{13} \mathrm{C}\right]$ Leu during the infusion period was not affected by diet (Table 6; Figure 3), although there was a tendency for a higher enrichment of the whole casein fraction during late lactation (Table 6). At both stages of lactation, at the end of $\left[1-{ }^{13} \mathrm{C}\right]$ Leu infusion $(6,7,8 \mathrm{~h}$ after the start of infusion) the enrichment appeared to reach a plateau in HS-fed cows, whereas in LS-fed cows the enrichment continued to rise. This resulted in higher isotopic enrichment compared with HS-fed cows (29.1 vs. $27.0 \triangle \mathrm{PDB}$, for pooled data at $8 \mathrm{~h}$ in LS vs. HS, respectively, $P<0.05)$.

Whole-body protein flux rate (WBPF; Table 6) did not differ by diet or stage of lactation. The proportion of mammary gland protein (MGP) output of WBPF (Table 6) was not affected by diet in early lactation,

Table 6. Least squares means of whole-body keto-isocaproate atom percent enrichment (KIC-APE), leucine irreversible loss rate (Leu-ILR), casein (expressed as difference from Pee-Dee Belemnite as reference, $\triangle \mathrm{PDB}$ ), whole-body protein flux (WBPF), and its proportion in mammary gland protein (MGP) output in dairy cows fed 28-d diets with high (HS) and low (LS) starch plus sugar contents during early and late lactation [calculation done on last day (d 28) of each dietary period and in both stages of lactation]

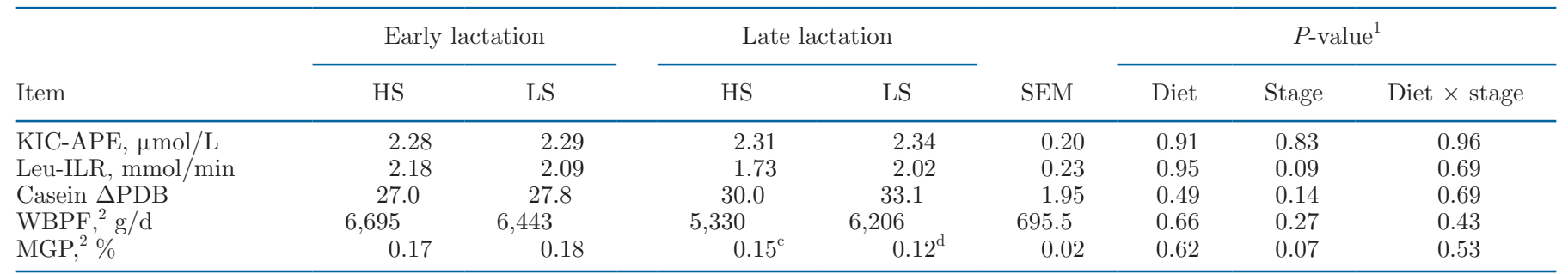

${ }^{c, d}$ Least squares means in the same row and within a stage of lactation without a common superscript differ at $P<0.1$.

${ }^{1}$ Stage $=$ stage of lactation; diet $\times$ stage $=$ interaction between diet and stage of lactation.

${ }^{2}$ Calculated from Leu-ILR as proposed by Bequette et al. (1996). 


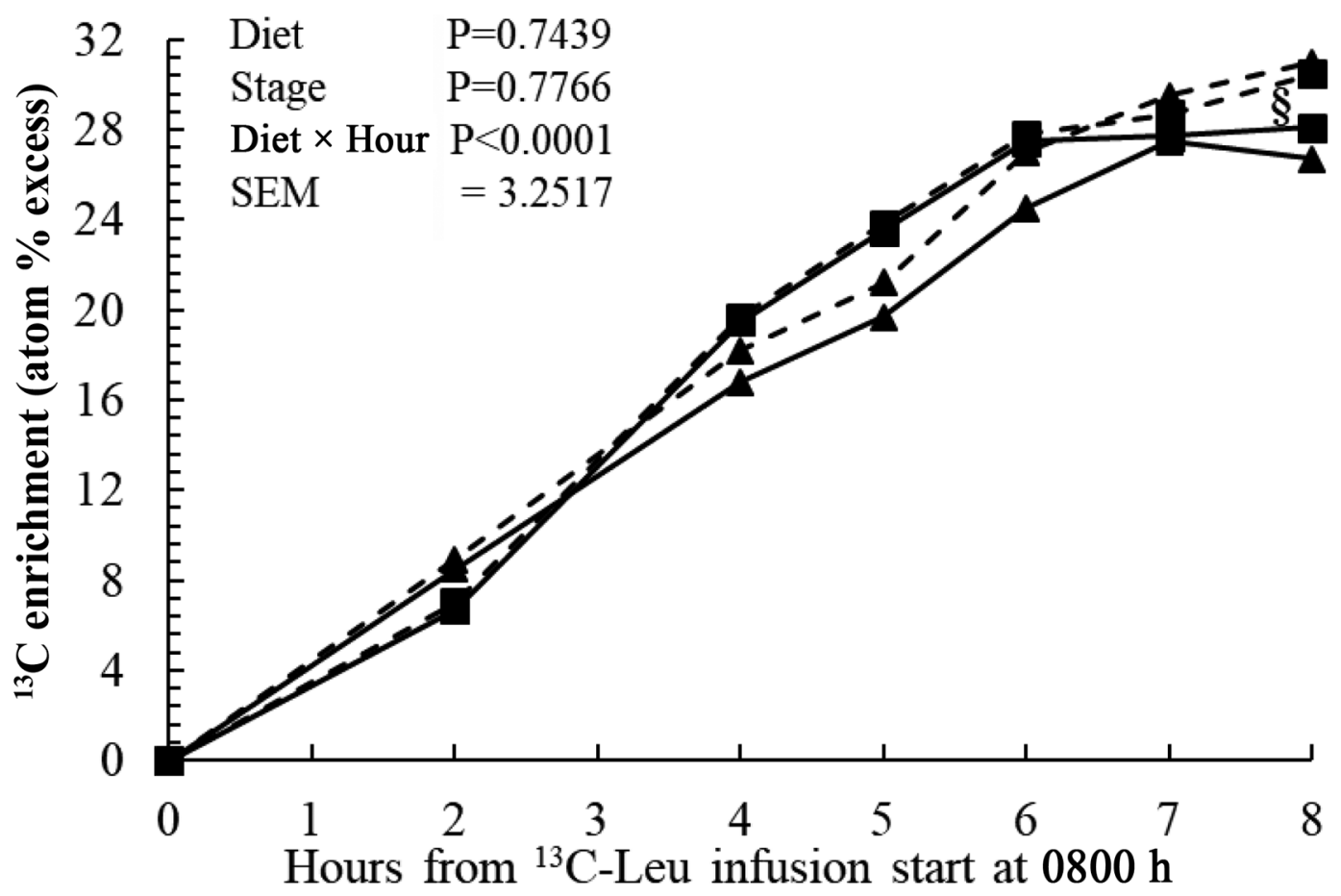

Figure 3. Changes in ${ }^{13} \mathrm{C}$-enrichment of casein during intravenous infusion of $\left[1-{ }^{13} \mathrm{C}\right]$ leucine in dairy cows in early $(\boldsymbol{\square})$ and late $(\boldsymbol{\Lambda})$ lactation fed 28-d diets with high (HS; - ) and low (LS; - - -) starch and sugar content; infusion was performed on d 28. $\S$ indicates a significant difference at $P<0.05$ between HS and LS diets for plateau values (mean of difference with respect to Pee-Dee Belemnite at time zero at 6 , 7 , and $8 \mathrm{~h}$ after start of infusion).

whereas in late lactation the proportion was lower in LS-fed compared with HS-fed cows.

\section{Milk Yield and Characteristics}

Mean values of milk yield and parameters measured on bulked milk are shown in Table 7, whereas parameters measured in milk samples from the morning milking are shown in Table 8. Milk yield was similar for both diet groups (Table 7) at both stages of lactation. As expected, milk yield was approximately $50 \%$ higher in early compared with late lactation. In late lactation, milk fat output was lower in HS- compared with LS-fed cows (Table 7; $P<0.05$ ), whereas in early lactation there was no difference.

Protein concentration in bulked milk was greater $(P$ $<0.05)$ in late lactation in HS-fed compared with LSfed cows (Table 7). The concentration of casein fraction in bulked milk (Table 7) tended to be higher $(P=$ $0.06)$ and its yield was higher $(P<0.01)$ during early compared with late lactation. Among casein fractions, differences between diets were observed only in late lactation, where higher $\alpha$-casein and lower $\kappa$-casein contents were observed in milk from HS-fed compared with LS-fed cows $(P<0.10)$. Yield, as well as content of whey protein fractions ( $\alpha$-LA, $\beta-\mathrm{LG}, \mathrm{BSA}$, and immunoglobulin), were not modified by stage of lactation or diet (Table 7). Urea nitrogen concentration in bulked milk was higher in late compared with early lactation $(P=0.02)$ and lower in milk from HS-fed compared with LS-fed cows in early lactation $(P<0.05$; Table 7). In late lactation, concentrations of $\mathrm{Ca}$ and $\mathrm{P}$ were greater in milk from HS-fed compared with milk from LS-fed cows.

In morning milk, fat content was greater in LS-fed cows (effect of diet was significant for $P=0.01$, Table 8 ), whereas protein content (Table 8) was greater in HS-fed cows (effect of diet was significant for $P<0.01$ ). The $\mathrm{pH}$ of morning milk was higher in late compared with early lactation $(P=0.02$, Table 8$)$ and in late lactation it was greater in milk from HS-fed compared with LS-fed cows $(P<0.10$, Table 8$)$. Titratable acidity was higher in milk during early compared with late lactation $(P<0.01$, Table 8$)$.

The response to diet on milk protein clotting was different in the 2 stages of lactation (Table 8 ). In early lactation, curd firming rate tended to be greater in milk from HS-fed compared with LS-fed cows $(P=0.07)$, whereas in late lactation curd firming rate tended to be lower $(P=0.08)$ and curd firmness greater $(P<0.05)$ in milk from HS-fed compared with LS-fed cows. 
Table 7. Average milk yield, milk protein composition and characteristics of daily bulked milk of dairy cows fed 28-d diets with high (HS) and low (LS) starch plus sugar contents during early and late lactation (LSM of 3 samples collected every $3-4 \mathrm{~d}$ during the last $7 \mathrm{~d}$ of the period)

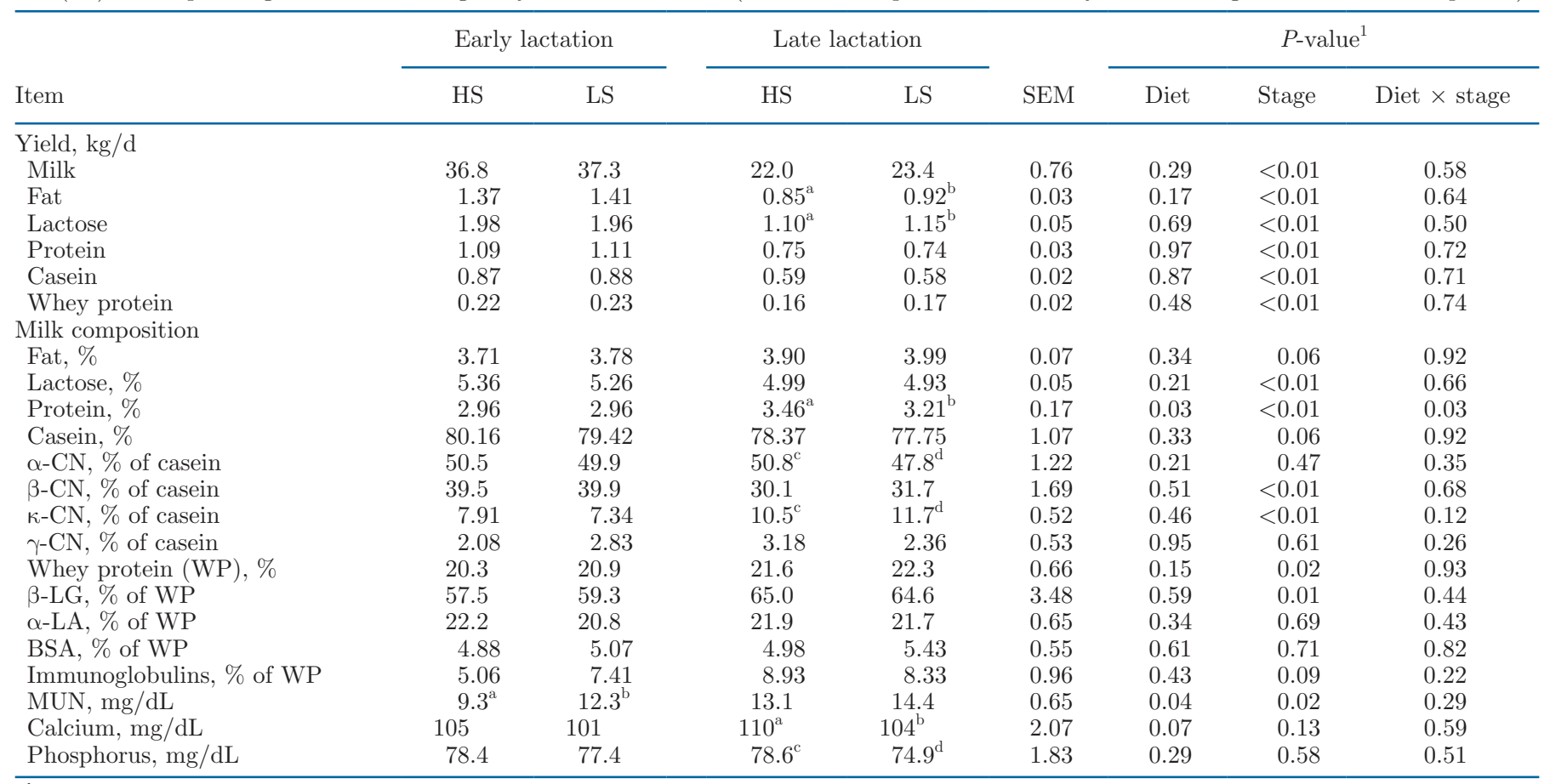

${ }^{\mathrm{a}, \mathrm{b}}$ Least squares means in the same row and within a stage of lactation without a common superscript differ at $P<0.05$.

${ }^{\mathrm{c}, \mathrm{d}}$ Least squares means in the same row and within a stage of lactation without a common superscript differ at $P<0.1$.

${ }^{1}$ Stage $=$ stage of lactation; diet $\times$ stage $=$ interaction between diet and stage of lactation.

\section{DISCUSSION}

\section{Diet}

Diets used in this study were formulated to provide different rates of ruminal fermentation and yield of VFA. To achieve this, diets differed in levels of starch and NDF, while maintaining similar dietary $\mathrm{N}$ levels. At both stages of lactation DMI was similar within the 2 diets and this was achieved by the regular distribution of feed over the day (i.e., chopped forages every 12 $\mathrm{h}$ and concentrates every $3 \mathrm{~h}$ ). This suggests that there was no restriction on intake for both diets, probably due to the low ADL content of the forages (Table 2), with

Table 8. Average composition and characteristics of morning milk of dairy cows fed 28-d diets with high (HS) and low (LS) starch plus sugar contents during early and late lactation (LSM of 5 samples collected every 3 to $4 \mathrm{~d}$ during last $14 \mathrm{~d}$ of the period)

\begin{tabular}{|c|c|c|c|c|c|c|c|c|}
\hline \multirow[b]{2}{*}{ Item } & \multicolumn{2}{|c|}{ Early lactation } & \multicolumn{2}{|c|}{ Late lactation } & \multirow[b]{2}{*}{ SEM } & \multicolumn{3}{|c|}{$P$-value ${ }^{1}$} \\
\hline & $\mathrm{HS}$ & $\mathrm{LS}$ & HS & $\mathrm{LS}$ & & Diet & Stage & Diet $\times$ stage \\
\hline Fat, $\%$ & $3.28^{\mathrm{a}}$ & $3.53^{\mathrm{b}}$ & 3.53 & 3.69 & 0.05 & 0.01 & 0.01 & 0.39 \\
\hline Protein, \% & $3.08^{\mathrm{c}}$ & $3.01^{\mathrm{d}}$ & $3.34^{\mathrm{a}}$ & $3.08^{\mathrm{b}}$ & 0.02 & $<0.01$ & $<0.01$ & 0.03 \\
\hline Lactose, \% & 5.29 & 5.25 & 4.90 & 4.86 & 0.08 & 0.28 & $<0.01$ & 0.94 \\
\hline $\mathrm{pH}$ & 6.68 & 6.68 & $6.74^{\mathrm{c}}$ & $6.70^{\mathrm{d}}$ & 0.02 & 0.16 & 0.02 & 0.15 \\
\hline $\mathrm{TA},{ }^{2}{ }^{\circ} \mathrm{SH} / 50 \mathrm{~mL}$ & 3.77 & 3.73 & 3.37 & 3.36 & 0.13 & 0.60 & $<0.01$ & 0.74 \\
\hline $\mathrm{RTC}^{3} \min$ & 20.84 & 19.98 & 22.14 & 23.42 & 1.86 & 0.85 & 0.12 & 0.39 \\
\hline $\mathrm{k} 20,{ }^{3} \min$ & $18.78^{c}$ & $16.84^{\mathrm{d}}$ & $17.94^{\mathrm{c}}$ & $19.97^{\mathrm{d}}$ & 3.62 & 0.98 & 0.56 & 0.33 \\
\hline $\mathrm{a} 30,{ }^{3} \mathrm{~mm}$ & 18.60 & 18.20 & $19.44^{\mathrm{a}}$ & $14.18^{\mathrm{b}}$ & 5.94 & 0.31 & 0.57 & 0.39 \\
\hline $\mathrm{SCC}, \log \mathrm{N} / \mu \mathrm{L}$ & 1.71 & 1.76 & 2.18 & 2.14 & 0.16 & 0.96 & 0.01 & 0.56 \\
\hline
\end{tabular}

\footnotetext{
${ }_{\mathrm{a}, \mathrm{b}}^{\mathrm{b}}$ east squares means in the same row and within a stage of lactation without a common superscript differ at $P<0.05$.

${ }^{\mathrm{c}, \mathrm{d}}$ Least squares means in the same row and within a stage of lactation without a common superscript differ at $P<0.1$.

${ }^{1}$ Stage $=$ stage of lactation; diet $\times$ stage $=$ interaction between diet and stage of lactation

${ }^{2} \mathrm{TA}=$ total acidity; $\mathrm{SH}=$ Soxhlet-Henkel.

${ }^{3} \mathrm{RTC}=$ rennet clotting time; $\mathrm{k} 20=$ curd firming rate; a30 $=$ curd firmness.
} 
both diets providing adequate fermentable material for ruminal microorganisms, with the HS diets promoting greater ruminal propionate production at the expense of acetate (Seal et al., 1992; Bannink et al., 2006; Agle et al., 2010).

The lack of difference for calculated FOM between the groups within each stage of lactation suggested that the predicted supply of microbial protein flowing into the small intestine was likely similar in amount (INRA, 2018) and composition (Hanigan et al., 1998; Brito et al., 2014). The lack of differences in microbial protein synthesis efficiency in response to substituting starch with beet pulp (Voelker and Allen, 2003) supports the lack of effect on FOM. Using the DMI (Table 3) and milk protein output (Table 8 ), the amount of digestible $\mathrm{AA}$ in the gut and AA balance were calculated using the protocol proposed by INRA (2018). The results of this calculation are shown in the Supplemental File S3. Briefly, there was a positive balance for most of the AA with the exception of His and Phe, for which intakes were slightly lower in early lactation and for both diets. Balance of Phe was slightly lower ins LS-fed cows in late lactation. One of the reasons for this negative balance could be the low rate of AA extraction by the portal-drained viscera calculated from data presented in Lapierre et al. (2012), which was 0.34 for His and 0.48 for Phe. We were not able in this study to measure the effects of the 2 diets on AA balance, but AA flow was estimated to avoid differences in EAA content of metabolizable protein provided.

\section{Blood Metabolites and Hormones}

A diet high in fermentable carbohydrate promotes a fermentation profile with greater production of propionate and, consequently, greater availability of substrate for hepatic glucose synthesis (Aschenbach et al., 2010). Such effect is supported in our study by the greater blood glucose concentrations in HS-fed cows particularly during early lactation. Greater blood glucose in cows fed diets with high starch or sugar have been observed in other studies (Colin-Schoellen et al., 1995; van Knegsel et al., 2007). The greater glucose availability resulting from the HS diet was likely the cause of the greater concentrations of insulin also observed with these diets. The amplitude of the postprandial increase in insulin should be attributed to glucose availability.

The greater glucose and insulin concentrations seen here for HS compared with LS-fed cows were also observed in a similar study during early lactation (van Knegsel et al., 2007), and could be due to lower responsiveness of peripheral tissues to the hormone at the initial stages of lactation (Vernon and Sasaki, 1991). Greater insulin concentrations maintain glucose homeostasis, which may explain the lack of difference in blood glucose concentrations in cows fed diets with different starch content in late lactation. Concentrations of blood glucose affect bST concentration (Flux et al., 1984), resulting in a pattern of changes opposite to that of insulin (Herbein et al., 1985), and results of our study confirmed this; both average (Table 4) and daily (Figure 2) bST concentrations were numerically greater when the LS diet was fed. The different pattern of the 2 hormones resulted in a greater ratio of $\mathrm{bST} /$ insulin (Table 4) when cows were fed LS that contained higher amounts of rumen-digestible fiber.

The present study also revealed numerically greater concentrations of NEFA in cows fed the LS diet during early lactation. The reason for this observation was likely the lower glucose availability in LS-fed cows and the role of bST on promoting lipid mobilization from adipose tissue in particular when insulin is lower (i.e., lower glucose, lower insulin, higher bST, and hence higher NEFA; Burton et al., 1994). Under such metabolic conditions, the liver produces more ketone bodies including BHB (Hammon et al., 2009). The effect of a different $\mathrm{bST} /$ insulin ratio on use of the body reserves was confirmed by variations in BW during the trial. The lower bST/insulin ratio observed when HS diets were fed resulted in an increase in daily body weight variation $(\Delta \mathbf{B W})$ in the last $14 \mathrm{~d}$ of the study during both stages of lactation. In contrast, the resulting higher bST/insulin ratio when feeding LS diets was associated with a decrease in $\Delta \mathrm{BW}$ in early lactation, but a maintenance of $\Delta \mathrm{BW}$ in late lactation.

\section{Blood AA Profiles}

When the experiment was designed, the main aim was to investigate changes in AA metabolism in cows fed diets that alter blood availability of glucose and consequently the secretion patterns of insulin and bST. To avoid confounding effects of differences in microbial protein supply, diets were formulated to provide similar flows of microbial protein calculated by balancing ruminal flow of AA with RUP. This should have achieved an AA profile close to milk protein with all diets, and a similar ratios between calculated AA availability in blood and their output in milk protein (Supplemental File S3) seemed to confirm this. Differences among metabolites and hormones described above suggested that the metabolic target was achieved.

Plasma AA concentrations observed in this experiment were within the ranges reported in other studies with dairy cows, across a range of different diets, sampling times, and stages of lactations as reviewed by Patton et al. (2015). Among papers reporting AA variations in plasma of dairy cows, to our knowledge, 
none has investigated the effect of meal on changes in plasma AA concentrations. For example, in the observations reported by Patton et al. (2015), while considering more than 100 studies in their meta-analysis, they were unable to consider the effect of meal. Furthermore, some studies collected blood after a meal, but pooled the samples for AA analysis (for example, Mabjeesh et al., 1999; Korhonen et al., 2002).

In the present study, collection of blood samples after a meal was done because in our experience postprandial metabolic changes have important effects on blood metabolites (i.e., glucose, NEFA, BHB) and hormones (i.e., insulin, bST, thyroid hormones), with marked differences between early or mid to late lactation (Bertoni et al., 1995; Piccioli-Cappelli et al., 2014). In the present study, we also confirmed there are changes in AA plasma profiles after a meal and these are affected by diet and stage of lactation.

Blood AA concentrations in peripheral blood might be expected to rise due to their absorption by the gut, as the liver accounts for the removal of about $43 \%$ of absorbed $\alpha$-amino nitrogen (Reynolds et al., 1988) and there is a linear relationship between portal-drained visceral flux of $\alpha$-amino nitrogen in whole blood (Seal and Reynolds, 1993). Moreover, Lapierre et al. (2012) reported that all EAA have a positive portal-drained visceral balance and that liver removes only a fraction of His, Met, Phe, Thr, and Tyr. In addition, higher AA concentrations in cows fed HS diets would have expected, as the higher amount of starch reaching the gut should have spared more AA (Seal and Reynolds, 1993; Piccioli-Cappelli et al., 1996). However, we observed a decrease in plasma AA concentrations after a meal, more evident when the HS diet was fed and in early compared with late lactation. This decrease did not seem to have been due to differences in the flow of AA into the small intestine because at both stages of lactation and with both diets the requirements for microbial protein were largely satisfied. This was surmised because the estimated total digestible AA (Table 1) was adequate for the level of milk protein output measured.

The decrease in AA after the forage meal could have been due to hormonal changes and particularly to the observed different responses in insulin and bST between diets and stage of lactation. The relationship of these 2 hormones with AA metabolism arises from the fact that in ruminants insulin is more effective in reducing protein catabolism than increasing protein synthesis in peripheral tissues (Crompton and Lomax, 1987a,b) with bST acting to reduce the responsiveness of peripheral tissues to insulin (Vernon and Sasaki, 1991). This combination of effects results, in conditions when insulin concentrations in plasma are higher, in lower plasma AA concentrations (Prior and Smith, 1983; Mackle et al., 1999).

In our experiment, at both stages of lactation, feeding LS diets resulted in a greater bST/insulin ratio indicating potentially a more catabolic condition compared with feeding HS diets. This suggested that when feeding LS diets, the peripheral tissue protein breakdown remained high because of lower insulin and higher bST concentrations. As such, the higher flux of AA from peripheral tissues helped to maintain AA concentrations in blood. The role of insulin on the reduction of protein breakdown and AA oxidation [i.e., higher protein retention by peripheral tissues (Lobley, 1992; Reynolds et al., 2001; Lapierre et al., 2002)] is in agreement with the lower rate of Leu-ILR in late lactation reported here.

Studies with beef steers showed that lower Leu oxidation was correlated with an increased in protein retention (Lapierre et al., 1999), with a consequent lower flow of AA from these tissues. The different fate of AA with the LS and HS diets also was supported by the lower isotope enrichment at the plateau $(6-8 \mathrm{~h}$ from start of infusion) for casein in pooled data for milk from HS-fed cows compared with LS-fed cows, perhaps indicating a lower availability of free Leu in the plasma pool (Figure 3). A difference in protein metabolism could also be the explanation for the lower His concentrations during late than early lactation. In fact, protein synthesis in peripheral tissues may have a higher demand for His than milk protein synthesis, an idea we surmise from the fact that His content of meat protein is about $4.2 \%$ (McCance and Widdowson, 1978) compared with a value of about $2.7 \%$ in milk protein (Alais, 1984).

In our calculations for diet formulation, the His content in AADG was determined on milk protein content (Supplemental File S2) and this could have unintentionally resulted in lower His availability in late lactation. This suggestion also is supported by the lack of a fall in plasma His after meals in cows fed LS in early lactation, a response indicative of the contribution of AA derived from proteolysis in peripheral tissue to the AA pool in blood. This may also have covered the slight deficit in the supply of microbial protein-His in the gut. In turn, all these suggestions are partly supported by the marked body weight loss $(\Delta \mathrm{BW}$; Table 2$)$ observed in the cows fed LS in early lactation.

The supply of the Met, Lys, and His is often considered rate-limiting for milk protein synthesis. In our study in early-lactating cows fed HS, the reduction in plasma concentrations at $8 \mathrm{~h}$ relative to pre-feeding values (time zero) for Met, Lys, and His, was $27.9 \%$, $33.6 \%$, and $38.5 \%$, respectively. The fall in plasma AA 
concentrations after the meal did not appear to limit milk synthesis as MGP output was similar between diets. Even at their lowest point, plasma Met, Lys, and His concentrations were still within the ranges reported by Patton et al. (2015), supporting the suggestion by the same authors that plasma AA concentrations are not adequate indicators on which to determine whether individual AA can limit MGP synthesis. It should be noted that most of the studies in the meta-analysis of Patton et al. (2015) were carried out with cows in mid to late lactation and time from feeding of blood collection was not considered in the evaluation. In fact, also in our study in late-lactating cows the variations of plasma AA concentrations due to diet or distance from a meal were smaller. Nevertheless, variations in plasma AA concentrations observed in early lactation could suggest that availability of some AA in those cows may be suboptimal. In our experiment, in early lactating cows fed HS, we observed a marked reduction of most AA after a meal, but in this group the synthesis of MGP did not seem to be affected probably due to the ability of the mammary gland to efficiently extract AA from the blood even at low concentrations (Lee et al., 2015).

Patton et al. (2015) reported a marginal effect of dietary energy level on plasma AA, and some studies have considered the effect of level of energy supply (Colin-Schoellen et al., 1995; Rius et al., 2010) or rate of glucose supply $(0,443,963$, and $2,398 \mathrm{~g} / \mathrm{d})$ by continuous infusion into the duodenum (Rulquin et al., 2004). These studies were performed using mid- to late-lactating cows and did not show any difference in AA concentrations between treatments. Results that are consistent with those observed in our study in late lactation, where no differences were observed between the 2 diets (Table 4 ).

The lower MUN seen in HS- compared with LS-fed cows (Table 7) indicated, at least in early lactation, a better net protein balance with a diet that provided more glucogenic precursors. It is well known that an increase in dietary energy results in a more efficient utilization of the CP supply (Colin-Schoellen et al., 1995; Hristov and Ropp, 2003; Rius et al., 2010). However, from our results, it was evident that also with isoenergetic diets, the efficiency of $\mathrm{CP}$ utilization can be affected by the rate of carbohydrate fermentability in the rumen. As stated above, diets lower in starch produced less of the glucogenic precursor propionate and this was confirmed by lower insulin in plasma of LS-fed cows. In an earlier study in which the same diets were fed, we showed that glucagon concentrations were greater in LS-fed cows (Piccioli-Cappelli et al., 2014), a response that could stimulate AA deamination in the liver (Bobe et al., 2009).

\section{Milk Yield and Characteristics}

During the experiment, the 2 milkings were carried out at 14- and 10-h intervals; thus, the milk obtained did not have the same characteristics, as some evidence suggests an effect of milking interval and circadian rhythm on composition (Harvatine, 2020). Consequently, to generate a more complete picture of the effect of diet we reconstituted a bulked sample representative of daily milk output (Table 7). In addition, morning milk was also analyzed (Table 8).

At both early and late lactation, milk yield was not affected by the rate of carbohydrate fermentability in the rumen, as already observed in similar studies (van Knegsel et al., 2007; Piccioli-Cappelli et al., 2014). Milk SCC throughout the study was always below the limits of normal ranges, indicating that the diets at both stages of lactation did not affect the functionality of the mammary parenchyma. This was confirmed by the low proportion of BSA in whey protein, which increases dramatically as a result of udder injury due to an infection (Jenness, 1985).

Feeding diets with low versus high starch resulted, as discussed above, in a greater bST:insulin ratio. In LS-fed cows, this led to increased mobilization of body lipid stores, resulting in greater blood concentrations of NEFA and BHB, and subsequently increased availability of precursors for milk fat synthesis. As a consequence, in early-lactation feeding the LS diet resulted in a slightly higher fat content in milk collected in the morning, and in bulked milk in late lactation there was a numerically higher milk fat content and output. We did not expect an effect of fermentable fiber intake since the ruminal acetate production should not have been altered (Hristov and Ropp, 2003). Furthermore, van Knegsel et al. (2007) observed similar results in early lactating cows at the metabolic level and a significant increase of milk fat content and output when feeding isoenergetic diets with low or high starch content (95 vs. $297 \mathrm{~g} / \mathrm{kg}$ of DM) which were more different than our diets (181 vs. 246 $\mathrm{g} / \mathrm{kg}$ of DM). Studies with cows fed isoenergetic diets during mid to late lactation involved mainly the use of dietary fat (Nichols et al., 2018) or different levels of energy in the diet (Rius et al., 2010), and resulted in greater milk fat content and yield when the source of glucogenic precursors was lower. Our results confirm these responses suggesting that the diets provided substrates, which increased glucose synthesis; the ensuing increase of insulin with the HS diet diverted nutrients toward peripheral tissues causing lower milk fat yield, but higher DBW gain.

The efficiency of utilization of CP for MGP synthesis was higher in early lactation (32.9 vs. $33.9 \%$, for HS and LS, respectively) compared with late lactation (25.2 vs. 
$24.9 \%$, for HS and LS, respectively) and did not differ between diets. This efficiency was consistent with the MUN content of the milk (i.e., lower in early lactation). In early lactation, the efficiency of $\mathrm{CP}$ utilization was similar to that calculated by Lee et al. (2015) using diets similar to those in this experiment for $\mathrm{CP}$ and $\mathrm{NE}_{\mathrm{L}}$. The efficiency observed in late-lactating cows was within the range observed by Rius et al. (2010) and Hristov and Ropp (2003). Efficiency could be considered normal at both stages of lactation and was likely due to the lower content of $\mathrm{CP}$ in our diets and the higher percentage of RUP with an AA profile similar to that of casein. As such, a high availability of microbial protein was ensured.

Although during early lactation diet type did not affect synthesis of individual milk protein fractions and mineral content of milk, feeding HS in late lactation led to faster coagulation (lower k20) and higher curd firmness (higher a30). Among the studies on the factors affecting MGP output, most have fed diets with different protein sources or different level or source (starch or fat) of energy, but none studied in detail milk protein composition and their clotting features. Increasing the EAA and energy supply results in greater MGP output and in some studies a greater casein content was also observed. For instance, Colin-Schoellen et al. (1995) fed early-lactation cows diets with raw or formaldehydetreated soybean meal together with rumen-protected Met and Lys and observed an increase in MGP and casein content. However, AA supplementation did not alter MGP composition. Combining rumen-protected Met plus rumen-protected Lys with 2 levels of $\mathrm{NE}_{\mathrm{L}}$ (1.72 and $1.58 \mathrm{Mcal} / \mathrm{kg}$ of $\mathrm{DM}$ ) also did not change MGP.

To our knowledge, only one study has investigated the effect of diet composition on milk protein composition in late lactation. Donkin et al. (1989) added rumenprotected Met and Lys to a diet with $16.4 \%$ of CP and $1.62 \mathrm{kcal} / \mathrm{kg}$ of $\mathrm{DM}$ of $\mathrm{NE}_{\mathrm{L}}$ and observed an increase in the $\alpha-\mathrm{CN}$ and $\beta-\mathrm{CN}$ fractions along with a decrease in the $\mathrm{k}$-CN fraction. In the current study, in late lactation there was a decrease in $\mathrm{k}$-casein and an increase in the $\alpha-\mathrm{CN}$ fraction along with greater content of $\mathrm{P}$ and $\mathrm{Ca}$ in milk from cows fed HS compared with LS. The greater $\alpha$-CN fraction in the HS-fed group could have been related to the higher milk content of $\mathrm{P}$, since this mineral is most concentrated in the $\alpha$-casein fraction. All these variables are consistent with improved milk coagulation properties (lower k20 and higher a30) in milk from HS-fed cows. $\kappa$-Casein serves to stabilize casein micelles (McGann et al., 1980), and its lower content facilitates rennet activity (lower k20), whereas a greater $\alpha-\mathrm{CN}, \mathrm{P}$, and $\mathrm{Ca}$ content contributed to the higher strength of the casein clot (higher a30).

\section{CONCLUSIONS}

Diets with different rate of ruminal carbohydrate fermentability (starch or fiber) alter plasma glucose concentrations of dairy cows in both the early and mid-late stage of lactation, which in turn affect the bST:insulin ratio. This change alters nutrient availability, and in particular higher NEFA in early lactation when the diet was higher in ruminally fermentable fiber, resulting in a slightly higher milk fat content and output. A diet with higher ruminally fermentable starch reduced blood concentration of most AA and particularly in the early-lactation stage, but no effects were observed on milk protein output. These results indicate that there is an interaction between fermentability of the diet, stage of lactation, blood availability of nutrients, and milk characteristics, and among the latter also milk clotting features. This suggests the possibility of obtaining an output of milk protein with a specific composition suitable for industrial processing.

\section{ACKNOWLEDGMENTS}

This project was partially supported by Minisero Italiano delle Politiche Agricole e Forestali (MiPAAF) FILIGRANA fund (D.M. 25741/7303/11-01/12/2011) and by the Romeo and Enrica Invernizzi Foundation, Milan, Italy. The authors are grateful to Emeritus Professor Giuseppe Bertoni (Università Cattolica del Sacro Cuore, Piacenza, Italy) for the advice and assistance during the planning and realization of the experiment. The authors have not stated any conflicts of interest.

\section{REFERENCES}

Agle, M., A. N. Hristov, S. Zaman, C. Schneider, P. M. Ndegwa, and V. K. Vaddella. 2010. Effect of dietary concentrate on rumen fermentation, digestibility, and nitrogen losses in dairy cows. J. Dairy Sci. 93:4211-4222. https://doi.org/10.3168/jds.2009-2977.

Alais, C. 1984. Scienza Del Latte. Principi Di Tecnologia Del Latte e Dei Derivati. Tecniche N. Milan, Italy.

AOAC International. 2012. Official Methods of Analysis. 19th ed AOAC International.

Aschenbach, J. R., N. B. Kristensen, S. S. Donkin, H. M. Hammon, and G. B. Penner. 2010. Gluconeogenesis in dairy cows: The secret of making sweet milk from sour dough. IUBMB Life 62:869-877. https://doi.org/10.1002/iub.400.

Bach, A., G. B. Huntington, S. Calsamiglia, and M. D. Stern. 2000. Nitrogen metabolism of early lactation cows fed diets with two different levels of protein and different amino acid profiles. J. Dairy Sci. 83:2585-2595. https://doi.org/10.3168/jds.S0022-0302(00)75152 -6 .

Bannink, A., J. Dijkstra, S. Koopmans, and Z. Mroz. 2006. Physiology, regulation and multifunctional activity of the gut wall: A rationale for multicompartmental modelling. Nutr. Res. Rev. 19:227-253. https://doi.org/10.1017/S0954422407334094.

Barbano, D. M., and J. W. Sherbon. 1984. Cheddar cheese yields in New York. J. Dairy Sci. 67:1873-1883. https://doi.org/10.3168/jds .S0022-0302(84)81517-9. 
Bauman, D. E. 2000. Regulation of nutrient partitioning during lactation: Homeostasis and homeorhesis revisited. Pages 311-328 in Ruminant Physiology: Digestion, Metabolism, Growth and Reproduction. CABI International.

Bequette, B. J., J. A. Metcalf, D. Wray-Cahen, C. F. R. Backwell, J. D. Sutton, M. A. Lomax, J. C. Macrae, and G. E. Lobley. 1996. Leucine and protein metabolism in the lactating dairy cow mammary gland: responses to supplemental dietary crude protein intake. J. Dairy Res. 63:209-222. https://doi.org/10.1017/ S002202990003171X.

Bertoni, G., L. Calamari, and M. G. Maianti. 2001. Producing specific milks for specialty cheeses. Proc. Nutr. Soc. 60:231-246. https:// doi.org/10.1079/PNS200080.

Bertoni, G., R. Lombardelli, and V. Cappa. 1995. Metabolite and hormone diurnal variations in the physiological phases of dairy cows. Zootec. Nutr. Anim. 21:271-283.

Bobe, G., A. R. Hippen, P. She, G. L. Lindberg, J. W. Young, and D. C. Beitz. 2009. Effects of glucagon infusions on protein and amino acid composition of milk from dairy cows. J. Dairy Sci. 92:130-138. https://doi.org/10.3168/jds.2008-1450.

Brito, A. F., G. F. Tremblay, A. Bertrand, Y. Castonguay, G. Bélanger, R. Michaud, C. Lafrenière, R. Martineau, and R. Berthiaume. 2014. Alfalfa baleage with increased concentration of nonstructural carbohydrates supplemented with a corn-based concentrate did not improve production and nitrogen utilization in early lactation dairy cows. J. Dairy Sci. 97:6970-6990. https://doi.org/ 10.3168/jds.2013-7305.

Broderick, G. A. 2003. Effects of varying dietary protein and energy levels on the production of lactating dairy cows. J. Dairy Sci 86:1370-1381. https://doi.org/10.3168/jds.S0022-0302(03)73721 -7 .

Burton, J. L., B. W. McBride, E. Block, D. R. Glimm, and J. J. Kennelly. 1994. A review of bovine growth hormone. Can. J. Anim. Sci. 74:167-201. https://doi.org/10.4141/cjas94-027.

Buttery, P. J. 1977. Biochemical basis of rumen fermentation. Pages 8-24 in Recent Advances in Animal Nutrition. W. Haresign and L. Dyfed, ed. Butterworths.

Calamari, L., F. Piccioli-Cappelli, P. Bani, M. G. Maianti, and G. Bertoni. 2010. Effect of feeding dairy cows diets with different fermentable energy on milk cheese-making features. Pages 679-680 in 3rd EAAP International Symposium on Energy and Protein Metabolism and Nutrition. EAAP Publication.

Clark, J. H., T. H. Klusmeyer, and R. M. Cameron. 1992. Microbial protein synthesis and flows of nitrogen fractions to the duodenum of dairy cows. J. Dairy Sci. 75:2304-2323. https://doi.org/10 .3168/jds.S0022-0302(92)77992-2.

Colin-Schoellen, O., F. Laurent, B. Vignon, J. C. Robert, and B. Sloan. 1995. Interactions of ruminally protected methionine and lysine with protein source or energy level in the diets of cows. J. Dairy Sci. 78:2807-2818. https://doi.org/10.3168/jds.S0022 -0302(95)76911-9.

Crompton, L. A., and M. A. Lomax. 1987a. Effect of undernourishment and subsequent refeeding on hind-limb muscle protein metabolism in growing lambs. Proc. Nutr. Soc. 46:44. (Abstr.)

Crompton, L. A., and M. A. Lomax. 1987b. The relationship between hind-limb muscle protein metabolism and growth hormone, insulin, thyroxine and cortisol in growing lambs. Proc. Nutr. Soc. 46:45. (Abstr.)

Davoli, R. 1981. Determinazione delle varianti genetiche delle proteine del latte mediante elettroforesi su acetato di cellulosa. Riv. Zootec. Vet. 9:96-100.

DePeters, E. J., and J. P. Cant. 1992. Nutritional factors influencing the nitrogen composition of bovine milk: A review. J. Dairy Sci. 75:2043-2070. https://doi.org/10.3168/jds.S0022-0302(92)77964 -8 .

Donkin, S. S., G. A. Varga, T. F. Sweeney, and L. D. Muller. 1989. Rumen-protected methionine and lysine: effects on animal performance, milk protein yield, and physiological measures. J. Dairy Sci. 72:1484-1491. https://doi.org/10.3168/jds.S0022-0302(89)79258 -4 .
Edmonson, A. J., I. J. Lean, L. D. Weaver, T. Farver, and G. Webster. 1989. A body condition scoring chart for Holstein dairy cows. J. Dairy Sci. 72:68-78. https://doi.org/10.3168/jds.S0022 -0302(89)79081-0.

Evans, E. H., and R. J. Patterson. 1985. Use of dynamic modeling seen as good way to formulate crude protein, amino acid requirements for cattle diets. Feedstuffs 57:24.

Faul, F., E. Erdfelder, A. G. Lang, and A. Buchner. 2007. G*Power 3: A flexible statistical power analysis program for the social, behavioral, and biomedical sciences. Behav. Res. Methods 39:175-191. https://doi.org/10.3758/BF03193146.

Flux, D. S., D. D. S. Mackenzie, and G. F. Wilson. 1984. Plasma metabolite and hormone concentrations in Friesian cows of differing genetic merit measured at two feeding levels. Anim. Sci. 38:377-384. https://doi.org/10.1017/S0003356100041568.

Ganev, G., E. R. Ørskov, and R. Smart. 1979. The effect of roughage or concentrate feeding and rumen retention time on total degradation of protein in the rumen. J. Agric. Sci. 93:651-656. https://doi .org/10.1017/S002185960003906X.

Hammon, H. M., G. Stürmer, F. Schneider, A. Tuchscherer, H. Blum, T. Engelhard, A. Genzel, R. Staufenbiel, and W. Kanitz. 2009. Performance and metabolic and endocrine changes with emphasis on glucose metabolism in high-yielding dairy cows with high and low fat content in liver after calving. J. Dairy Sci. 92:1554-1566. https://doi.org/10.3168/jds.2008-1634.

Hanigan, M. D., J. P. Cant, D. C. Weakley, and J. L. Beckett. 1998. An evaluation of postabsorptive protein and amino acid metabolism in the lactating dairy cow. J. Dairy Sci. 81:3385-3401. https: //doi.org/10.3168/jds.S0022-0302(98)75903-X.

Harding, F., and K. R. Marshall. 1998. Terminology for milk protein fractions. Bulletin of the IDF 329:30-31.

Harvatine, K. J. 2020. New insights in milk fat research and reviewing our progress. Pages 1-8 in 82nd Cornell Nutrition Conference. Cornell University.

Herbein, J. H., R. J. Aiello, L. I. Eckler, R. E. Pearson, and R. M. Akers. 1985. Glucagon, insulin, growth hormone, and glucose concentrations in blood plasma of lactating dairy cows. J. Dairy Sci. 68:320-325. https://doi.org/10.3168/jds.S0022-0302(85)80828-6.

Hristov, A. N., and J. K. Ropp. 2003. Effect of dietary carbohydrate composition and availability on utilization of ruminal ammonia nitrogen for milk protein synthesis in dairy cows. J. Dairy Sci. 86:2416-2427. https://doi.org/10.3168/jds.S0022-0302(03)73836 $-3$.

INRA (Institut National de la Recherche Agronomique). 2018. INRA Feeding System for Ruminants. Wageningen Academic Publishers.

Jenness, R. E. 1985. Lactation. Pages 164-197 in Biochemical and Nutritional Aspects of Milk and Colostrum. B. L. Larson, ed. The Iowa State University Press.

Korhonen, M., A. Vanhatalo, and P. Huhtanen. 2002. Effect of protein source on amino acid supply, milk production, and metabolism of plasma nutrients in dairy cows fed grass silage. J. Dairy Sci 85:3336-3351. https://doi.org/10.3168/jds.S0022-0302(02)74422 $-6$.

Lapierre, H., J. F. Bernier, P. Dubreuil, C. K. Reynolds, C. Farmer, D. R. Ouellet, and G. E. Lobley. 1999. The effect of intake on protein metabolism across splanchnic tissues in growing beef steers. Br. J. Nutr. 81:457-466. https://doi.org/10.1017/S0007114599000811. Lapierre, H., J. P. Blouin, J. F. Bernier, C. K. Reynolds, P. Dubreuil, and G. E. Lobley. 2002. Effect of supply of metabolizable protein on whole body and splanchnic leucine metabolism in lactating dairy cows. J. Dairy Sci. 85:2631-2641. https://doi.org/10.3168/ jds.S0022-0302(02)74348-8.

Lapierre, H., G. E. Lobley, L. Doepel, G. Raggio, H. Rulquin, and S. Lemosquet. 2012. Triennial Lactation Symposium: Mammary metabolism of amino acids in dairy cows. J. Anim. Sci. 90:1708-1721. https://doi.org/10.2527/jas.2011-4645.

Lee, C., F. Giallongo, A. N. Hristov, H. Lapierre, T. W. Cassidy, K. S. Heyler, G. A. Varga, and C. Parys. 2015. Effect of dietary protein level and rumen-protected amino acid supplementation on amino acid utilization for milk protein in lactating dairy cows. J. Dairy Sci. 98:1885-1902. https://doi.org/10.3168/jds.2014-8496. 
Littell, R., G. Milliken, W. Stroup, R. Wolfinger, O. Schabenberger, and S. Walter. 2006. SAS for Mixed Models, 2nd ed. SAS Institute Inc.

Lobley, G. E. 1992. Control of the metabolic fate of amino acids in ruminants: A review. J. Anim. Sci. 70:3264-3275. https://doi.org/ 10.2527/1992.70103264x.

Mabjeesh, S., I. Bruckental, and A. Arieli. 1999. Heat-treated whole cottonseed: Effect of dietary protein concentration on the performance and amino acid utilization by the mammary gland of dairy cows. J. Dairy Res. 66:9-22. https://doi.org/10.1017/ S0022029998003306.

Mackle, T. R., D. A. Dwyer, K. L. Ingvartsen, P. Y. Chouinard, J. M. Lynch, D. M. Barbano, and D. E. Bauman. 1999. Effects of insulin and amino acids on milk protein concentration and yield from dairy cows. J. Dairy Sci. 82:1512-1524. https://doi.org/10.3168/ jds.S0022-0302(99)75378-6.

Mantysaari, P. E., C. J. Sniffen, and J. D. O'Connor. 1989. An application model to balance amino acids for dairy cattle. Feedstuffs 61:13.

McCance, R. A., and E. Widdowson. 1978. The Composition of Foods. 4th ed. D. A. T. Southgate and A. A. Paul, ed. Her Majesty's Stationery Office.

McGann, T. C. A., W. J. Donnelly, R. D. Kearney, and W. Buchhemm. 1980. Composition and size distribution of bovine casein micelles. Biochim. Biophys. Acta, Gen. Subj. 630:261-270. https:/ /doi.org/10.1016/0304-4165(80)90430-4.

Molento, C. F. M., E. Block, R. I. Cue, and D. Petitclerc. 2002. Effects of insulin, recombinant bovine somatotropin, and their interaction on insulin-like growth factor-I secretion and milk protein production in dairy cows. J. Dairy Sci. 85:738-747. https://doi.org/10 .3168/jds.S0022-0302(02)74131-3.

Nichols, K., A. Bannink, S. Pacheco, H. J. van Valenberg, J. Dijkstra, and H. van Laar. 2018. Feed and nitrogen efficiency are affected differently but milk lactose production is stimulated equally when isoenergetic protein and fat is supplemented in lactating dairy cow diets. J. Dairy Sci. 101:7857-7870. https://doi.org/10.3168/jds .2017-14276.

NRC (National Research Council). 2001. Nutrient Requirements of Dairy Cattle. 7th rev. ed. National Academies of Science.

Oba, M., and M. S. Allen. 2003. Effects of diet fermentability on efficiency of microbial nitrogen production in lactating dairy cows. J. Dairy Sci. 86:195-207. https://doi.org/10.3168/jds.S0022 -0302(03)73600-5.

Palmquist, D. L., and T. C. Jenkins. 2017. A 100-year review: Fat feeding of dairy cows. J. Dairy Sci. 100:10061-10077. https://doi .org/10.3168/jds.2017-12924.

Patton, R. A., A. N. Hristov, C. Parys, and H. Lapierre. 2015. Relationships between circulating plasma concentrations and duodenal flows of essential amino acids in lactating dairy cows. J. Dairy Sci. 98:4707-4734. https://doi.org/10.3168/jds.2014-9000.

Piccioli-Cappelli, F. 2021. Piccioli-Cappelli_paper-aa_supplemental file.docx. figshare. Journal contribution. https://doi.org/10.6084/ m9.figshare.14706606.v2.

Piccioli-Cappelli, F., G. Bertoni, E. Trevisi, M. G. Maianti, and V. Cappa. 1996. Milk protein fraction changes after rbST treatment in dairy cows. Zootec. Nutr. Anim. 22:261-262.

Piccioli-Cappelli, F., J. J. Loor, C. J. Seal, A. Minuti, and E. Trevisi. 2014. Effect of dietary starch level and high rumen-undegradable protein on endocrine-metabolic status, milk yield, and milk composition in dairy cows during early and late lactation. J. Dairy Sci. 97:7788-7803. https://doi.org/10.3168/jds.2014-8336.

Piccioli-Cappelli, F., C. J. Seal, and D. S. Parker. 1997. Glucose and $\left[{ }^{13} \mathrm{C}\right]$ leucine metabolism by the portal-drained viscera of sheep fed on dried grass with acute intravenous and intraduodenal infusion of glucose. Br. J. Nutr. 78:931-946. https://doi.org/10.1079/ BJN19970210.

Prior, R. L., and S. B. Smith. 1983. Role of insulin in regulating amino acid metabolism in normal and alloxan-diabetic cattle. J. Nutr. 113:1016. https://doi.org/10.1093/jn/113.5.1016.

Reynolds, C. K., S. B. Cammell, D. J. Humphries, D. E. Beever, J. D. Sutton, and J. R. Newbold. 2001. Effects of postrumen starch infusion on milk production and energy metabolism in dairy cows. J. Dairy Sci. 84:2250-2259. https://doi.org/10.3168/jds.S0022 $-0302(01) 74672-3$.

Reynolds, C. K., G. B. Huntington, H. F. Tyrrell, and P. J. Reynolds. 1988. Net portal-drained visceral and hepatic metabolism of glucose, L-lactate, and nitrogenous compounds in lactating Holstein cows. J. Dairy Sci. 71:1803-1812. https://doi.org/10.3168/ jds.S0022-0302(88)79749-0.

Riis, P. M., A. Danfær, T. Hvelplund, A. Madsen, M. O. Nielsen, P. Henning Petersen, K. Sejrsen, and S. H. Thilsted. 1989. A model for efficient use of new information within physiology, nutrition and breeding of dairy cows. Report from the National Institute of Animal Science, Denmark.

Rius, A. G., M. L. McGilliard, C. A. Umberger, and M. D. Hanigan. 2010. Interactions of energy and predicted metabolizable protein in determining nitrogen efficiency in the lactating dairy cow. J. Dairy Sci. 93:2034-2043. https://doi.org/10.3168/jds.2008-1777.

Rohr, K., and P. Lebzien. 1991. Present knowledge of amino acid requirements for maintenance and production. Pages 127-138 in Proc. 6th Int. Symp. Protein Metabolism and Nutrition, Herning, Denmark. EAAP publication, 59.

Rulquin, H., S. Rigout, S. Lemosquet, and A. Bach. 2004. Infusion of glucose directs circulating amino acids to the mammary gland in well-fed dairy cows. J. Dairy Sci. 87:340-349. https://doi.org/10 .3168/jds.S0022-0302(04)73173-2.

Santos, F. A. P., J. E. P. Santos, C. B. Theurer, and J. T. Huber. 1998. Effects of rumen-undegradable protein on dairy cow performance: A 12-year literature review. J. Dairy Sci. 81:3182-3213. https://doi .org/10.3168/jds.S0022-0302(98)75884-9.

Seal, C. J., D. S. Parker, and P. J. Avery. 1992. The effect of forage and forage-concentrate diets on rumen fermentation and metabolism of nutrients by the mesenteric- and portal-drained viscera in growing steers. Br. J. Nutr. 67:355-370. https://doi.org/10.1079/ BJN19920041.

Seal, C. J., and C. K. Reynolds. 1993. Nutritional implications of gastrointestinal and liver metabolism in ruminants. Nutr. Res. Rev. 6:185-208. https://doi.org/10.1079/NRR19930012.

Storm, E., and E. R. Ørskov. 1983. The nutritive value of rumen micro-organisms in ruminants. Br. J. Nutr. 50:463-470. https://doi .org/10.1079/BJN19830114.

Tamminga, S., W. M. Van Straalen, A. P. J. Subnel, R. G. M. Meijer, A. Steg, C. J. G. Wever, and M. C. Blok. 1994. The Dutch protein evaluation system: The DVE/OEB system. Livest. Prod. Sci. 40:139-155. https://doi.org/10.1016/0301-6226(94)90043-4.

van Knegsel, A. T. M., H. van den Brand, J. Dijkstra, W. M. van Straalen, R. Jorritsma, S. Tamminga, and B. Kemp. 2007. Effect of glucogenic vs. lipogenic diets on energy balance, blood metabolites, and reproduction in primiparous and multiparous dairy cows in early lactation. J. Dairy Sci. 90:3397-3409. https://doi.org/10 .3168 /jds.2006-837.

Vernon, R. G., and S. Sasaki. 1991. Control of responsiveness of tissues to hormones. Page 155 in Physiological Aspects of Digestion and Metabolism in Ruminants. T. Tsuda, Y. Sasaki, and R. Kawashima, ed. Academic Press Inc.

Voelker, J. A., and M. S. Allen. 2003. Pelleted beet pulp substituted for high-moisture corn: 3. Effects on ruminal fermentation, $\mathrm{pH}$, and microbial protein efficiency in lactating dairy cows. J. Dairy Sci. 86:3562-3570. https://doi.org/10.3168/jds.S0022-0302(03)73961 -7 .

\section{ORCIDS}

F. Piccioli-Cappelli @ https://orcid.org/0000-0003-1277-7821

D. S. Parker (1) https://orcid.org/0000-0001-6558-341X

J. J. Loor ๑ https://orcid.org/0000-0003-1586-4365

A. Minuti (1) https://orcid.org/0000-0002-0617-6571

V. Lopreiato (ำ https://orcid.org/0000-0001-6965-7340

E. Trevisi $\odot$ https://orcid.org/0000-0003-1644-1911 